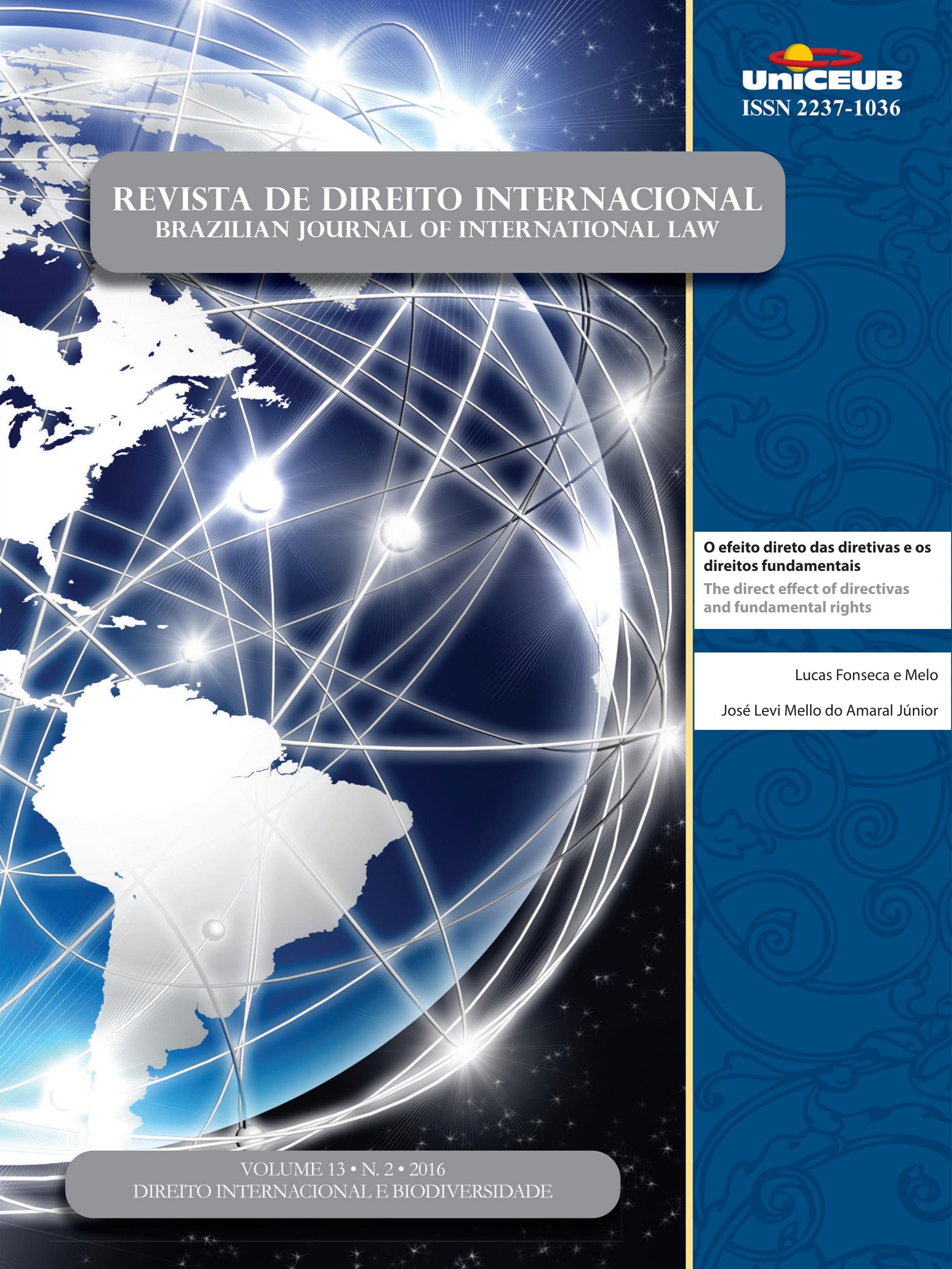




\section{Sumário}

CRÔNICAS DE DIREITO INTERNACIONAL PRIVADO 3 Gustavo Ferreira Ribeiro, Inez Lopes Matos Carneiro de Farias, Nadia de Araujo e Marcelo De Nardi

EDITORIAL 22

Márcia Dieguez Leuzinger e Solange Teles da Silva

IMPROVING THE EFFECTIVENESS OF LEGAL ARRANGEMENTS TO PROTECT BIODIVERSITY: AUSTRALIA AND BRAZIL .25

Paul Martin, Márcia Dieguez Leuzinger e Solange Teles da Silva

O RECONHECIMENTO DA DIGNIDADE DOS ELEMENTOS DA BIODIVERSIDADE COM BASE NO DIÁLOGO ENTRE O DIREITO INTERNACIONAL E O ORDENAMENTO JURÍDICO BRASILEIRO

Augusto César Leite de Resende

O REGIME INTERNACIONAL DO CLIMA E A PROTEÇÃO AOS “REFUgIADOS CLIMÁTICOS”: QUAIS DESAFIOS DA COP 21?

Ana Carolina Barbosa Pereira Matos e Tarin Cristino Frota Mont'Alverne

A anÁlise do MECANismo REdD+ COM Vistas À MitigaÇÃo dos EFEITOS DAS MUdANÇAS CLIMÁTICAS E À PROTEÇÃO DA DIVERSIDADE BIOLÓGICA FLORESTAL

Diogo Andreola Serraglio e Heline Sivini Ferreira

ECOLABELS DE EFICIÊNCIA ENERGÉtiCA E SUA CONSISTÊNCIA COM A DISCIPLINA DOS PPM's E PROVISÕES dOs Acordos GATT E TBT.

Cristiane Derani e Arthur Rodrigues Dalmarco

ANÁLISIS DEL ORDENAMIENTO JURÍDICO INTERNACIONAL SOBRE PROTECCIÓN DE LOS RECURSOS GENÉTICOS: DESAFIOS Y PERSPECTIVAS EN URUGUAY A PARTIR DE LA IMPLEMENTACIÓN DEL PROTOCOLO DE NAgOYA 115

Alina Celi 
LE RÉGIME INTERNATIONAL DE L'ACCÈS AUX RESSOURCES GÉNÉTIQUES AU PRISME DE L'ENTRÉE

en VIgUeUr du Protocole de NAgoya .............................................................. 131

Rodolpho Zahluth Bastos, Otávio Canto, Karine Galy e Isabelle Vestris

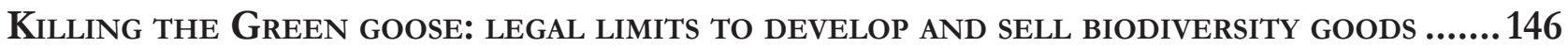
José Augusto Fontoura Costa e Liziane Paixão Silva Oliveira

VÍNCULO SUBSTANCIAL E AS BANDEIRAS DE CONVENIÊNCIA: CONSEQUÊNCIAS AMBIENTAIS DECORRENTES DOS NAVIOS COM REGISTROS ABERTOS ....................................................... 160

Marcos Edmar Ramos Alvares da Silva e André de Paiva Toledo

ANÁLISE DE CONTRATOS PÚblicos SOCIOAMBIENTAIS NO CENÁRIO PORTUGUÊS DE CRISE ECONÔ-

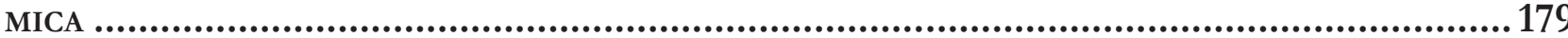

Alice Rocha da Silva e Matheus Passos Silva

A ORganizaÇão do TRATAdo DE COOPERAÇão AMAZÔNICA: UMA ANÁLISE CRÍTICA dAS RAZÕES POR TRÁS DA SUA CRIAÇÃO E EVOLUÇÃO

Paulo Henrique Faria Nunes

O uso de EXPERTS EM Controvérsias ambientais Perante a CorTe InTERnacional de JusTIÇA ........................................................................................................245

Lucas Carlos Lima

Os VIESES dA BIODIVERSIDAdE APRESENTAdos PELO CASO do PARQUE EÓlico DE BALd HiLls ......261 Natália Zampieri e Mariana Cabral

Mining CBD 275

Claire Lajaunie e Pierre Mazzega

Biotecnologia moderna, direito e o pensamento Abissal

Reichardt, F.V., Garavello, M. E. P. E., Molina, S.M.G. e Ballester, M. V. R.

Community Core Values como parâmetro de efetivação dos Princípios da Precaução e da Participação Popular em instrumentos de controle de projeto atividade de alta COMPLEXIDADE AMBIENTAL................................................................................... 314

Michelle Lucas Cardoso Balbino 
Discussões BIOTECNOLÓgICAS QUANTO AOS ORGANISMOS GENETICAMENTE MODIFICADOS NO ÂMBito da OMC: do contencioso ao acordo de vontades entre Argentina e União EuroPEIA

Gustavo Paschoal Oliveira

O Trans-Pacific Partnership Agreement e seus potenciais impactos para a regulação

DA BIODIVERSIDADE NO ÂMBITO TRANSNACIONAL..........................................................375

Mariana Yante Barrêto Pereira

AS ÁREAS PROTEGIDAS TRANSFRONTEIRIÇAS: REFLEXÕES CRÍTICAS ACERCA DE UM USO GEOPOLÍTICO DO DIREITO DA BIODIVERSIDADE.

Rabah Belaidi

O Que o caso Estados Unidos vs. Texas nos dirá sobre o direito de IMigração nos EsTADOS UNIDOS? 409

Danielle Anne Pamplona

Clóvis Beviláqua e a justiça internacional: entre o sim E o Não a Rui Barbosa.... .422 Paulo Emílio Vauthier Borges de Macedo

Possibilidade de delegação de atribuição para a Celebração de Tratados pela RepúbliCa Federativa do Brasil: análise do artigo 84, VIII c/c Parágrafo único da ConstituiÇão FEDERAL

Luciano Monti Favaro e Héctor Valverde Santana

Dignity, ubuntu, HUMANiTY AND AUTONOMOUS WEAPON SYSTEMS (AWS) DEBATE: AN AfRiCAN PERSPECTIVE 460

Thompson Chengeta

DiREITO INTERNACIONAL PRIVADO E O DIREITO TRANSNACIONAL: ENTRE A UNIFICAÇÃO E A ANARQUIA .503

André De Carvalho Ramos

A ilusória ausênCia do termo DépeÇage na JURisprudênCia brasileira de contratos INTERNACIONAIS

Gustavo Ferreira Ribeiro 
O EFEITO DIRETO DAS DIRETIVAS E OS DIREITOS FUNDAMENTAIS........................................535 Lucas Fonseca e Melo e José Levi Mello do Amaral Júnior

DA APLICABILIDADE DO BULK FACTORING AOS GRUPOS DE SOCIEDADES 565 Daniel Amin Ferraz e Leonardo Arêba Pinto

A Questão hermenêutica no direito das GENTES ................................................580 Inocêncio Mártires Coelho 


\title{
O efeito direto das diretivas e os direitos fundamentais
}

\section{The direct effect of directivas and fundamental rights}

\author{
Lucas Fonseca e Melo** \\ José Levi Mello do Amaral Júnior***
}

\section{Resumo}

$\mathrm{O}$ artigo analisa quais são os efeitos de uma diretiva e, a partir de quando, uma diretiva produz efeito jurídico. A metodologia utilizada no presente trabalho é a qualitativa, na modalidade estudo de caso, uma vez que o trabalho é focado na evolução da jurisprudência do Tribunal de Justiça da União Europeia sobre o tema. O objetivo específico é aprofundar no efeito direto horizontal das diretivas, tendo em vista as novas jurisprudências que reforçaram a invocabilidade direta dessas normas por particulares perante tribunais nacionais, nos casos em que elas concretizam direitos fundamentais. Ao final, conclui-se que uma diretiva pode ter efeito direto, em determinadas situações excepcionais.

Palavras-Chave: Diretivas. Direitos fundamentais. Efeito direto. Evolução jurisprudencial. Tribunal de Justiça da União Europeia.

* Autores convidados

O presente artigo é a versão revisada, corrigida e reduzida, pelo coorientador brasileiro, de relatório apresentado na disciplina de Direitos Fundamentais, sob a regência da Professora Doutora Maria Luísa Duarte, no curso de Doutoramento em Ciências Jurídico-Políticas da Faculdade de Direito da Universidade de Lisboa, em 2013

** Doutorando em Ciências Jurídico-Políticas em cotutela na Universidade de São Paulo e na Universidade de Lisboa. Assessor Especial do Ministro de Estado da Justiça e Cidadania. Procurador da Fazenda Nacional

*** Professor de Direito Constitucional da Faculdade de Direito da USP. Professor do Doutorado e Mestrado em Direito do UniCEUB. Secretário-Executivo do Ministério da Justiça e Cidadania. Procurador da Fazenda Nacional. E-mail: jose.levi@uol.com.br

\section{Abstract}

The article aims to analyze what are the effects of a directive and when a directive produces legal effect. A qualitative case study methodology is used since this study focuses on the evolution of the Court of Justice of the European Union's jurisprudence concerning directives. More specifically, it aims to look more closely and in depth the horizontal direct effect of directives in view of the new jurisprudence that allows for the direct application of directives by private citizens in national courts when directives embody fundamental rights. It is concluded that a directive may have a direct effect in certain exceptional situations.

Keywords: Directives. Direct effect. Evolution of jurisprudence. Court of Justice of the European Union.

\section{INTRODUÇÃo}

Determinar o efeito jurídico de uma diretiva não tem sido tarefa fácil, não pela simplicidade das suas disposições, no ordenamento jurídico da União Europeia, que regulam a matéria, mas pela evolução jurisprudencial que o 
tema sofreu e vem sofrendo no Tribunal de Justiça da União Europeia (TJUE). Essas alterações geram dúvidas, muitas ainda não completamente resolvidas. Não é a toa que Maria Luísa Duarte aduz que "a diretiva é o ato jurídico que exibe um maior grau de originalidade entre as formas jurídicas do querer normativo."

A complexidade do tema refere-se, especificamente, quanto aos verdadeiros destinatários da norma e a sua eficácia jurídica. Porém, o assunto ganha maior relevo quando essas diretivas concretizam direitos fundamentais.

Os direitos fundamentais alçaram, no decorrer da história, diferentes níveis hierárquicos no direito da União Europeia. Essa alternância ocorreu em vista da evolução jurisprudencial e das revisões formais nos Tratados Instituidores. Fato é que os efeitos jurídicos decorrentes dos atos que concretizam direitos fundamentais foram alterados, uma vez que os direitos fundamentais, após o Tratado de Lisboa, foram equiparados às demais fontes originárias do direito da União Europeia.

O presente trabalho enfrenta os seguintes problemas: quais são os efeitos de uma diretiva e a partir de quando uma diretiva produz efeito jurídico? As análises desses problemas são feitas a partir da evolução do tema na jurisprudência do TJUE.

O objetivo específico é aprofundar no efeito direto horizontal das diretivas, tendo em vista as novas jurisprudências que reforçaram a invocabilidade direta dessas normas por particulares perante tribunais nacionais, nos casos em que elas concretizam direitos fundamentais.

\section{FonTES dA UNIÃo EUROPEIA}

O direito da União Europeia forma um sistema jurídico autônomo, não se confundindo com o direito internacional ou com o direito interno de um Estado-membro. É composto por um conjunto de normas ordenadas hierarquicamente. Tem como caraterística singular a supranacionalidade. $\mathrm{Na}$ União Europeia, as Constituições dos Estados-membros permitem a delegação de competência a um Poder Supranacional. Assim, diferentemente do que ocorre na ordem jurídica

1 DUARTE, Maria Luísa. O tempo e a transposição de diretivas no direito da União Europeia. In: ESTUDOS em homenagem a Miguel Galvão Teles. Coimbra: Almedina, 2012. v. 1. p. 423-439. internacional clássica, a ordem jurídica da União Europeia pressupõe a partilha da soberania dos Estados-membros, que se submetem a uma ordem jurídica superior de caráter supranacional ${ }^{2}$.

O direito da União modifica e integra, direta ou indiretamente, o ordenamento dos Estados-membros, por meio das fontes secundárias. Percebe-se, assim, uma grande diferença entre a União Europeia e as obrigações oriundas de tratados internacionais, reguladas pelo direito internacional, uma vez que esse último pressupõe a autonomia dos ordenamentos nacionais frente às demais entidades internacionais e os outros países, sendo que qualquer alteração nos ordenamentos internos só é possível de ser concretizada pela via da ratificação.

As fontes do direito da União Europeia são o direito originário (fontes primárias), o direito derivado (fontes secundárias) e as fontes complementares ${ }^{3}$.

\subsection{Fontes Primárias}

As fontes primárias são atos jurídicos que contêm dispositivos inovadores, desvinculados de qualquer fundamento existente anteriormente. Denomina-se direito originário porque sobrevive aos acordos internacionais celebrados entre os Estados-membros, constituindo o fundamento dos atos jurídicos posteriores a serem expedidos pelos órgãos da União ${ }^{4}$.

O Direito primário ou originário integra o bloco de constitucionalidade da União Europeia (UE). Com-

2 FERREIRA, Lier Pires; FRAGOSO, Geraldo. O direito comunitário na União Europeia. VoxJuris, ano 1, v. 1, n. 1, p. 115-131, 2008. Disponível em: < https://ugf.br/files/stricto/direito/revista/14.artigo.07.pdf $>$ Acesso em: 05 ago. 2013.

3 As fontes complementares não serão objeto do presente trabalho, elas são compostas pelos seguintes institutos: a jurisprudência, a doutrina, o direito internacional, os tratados internacionais celebrados pela União e pelas comunidades com terceiro, os acordos mistos, os tratados internacionais concluídos pelos Estados membros com terceiros, os Tratados internacionais concluídos pelos Estados membros entre si, os atos unilaterais de organizações internacionais, acordos interinstitucionais, os atos atípicos e as conclusões e resoluções do conselho. Sobre o tema Cf. QUADROS, Fausto de. Direito da União Europeia. Coimbra: Almedina, 2004. p. 343-394; MARTINS, Ana Maria Guerra. Curso de direito constitucional da União Europeia. Coimbra: Almedina, 2004. p.373-420; CAMPOS, João Luiz Mota. Manual de direito europeu: o sistema institucional, a ordem jurídica e ordenamento económico da União Europeia. 6. ed. Coimbra: Coimbra, 2010. p. 295-352.

4 FORTE, Umberto. União Europeia: Comunidade Econômica Europeia: direito das Comunidades Europeias e harmonização fiscal. São Paulo: Malheiros, 1994. p. 31. 
preende um conjunto de instrumentos e princípios dotados de idêntica natureza e colocados no mesmo plano hierárquico normativo. O direito primário é "composto pelos tratados comunitários, isto é, pelos Tratados que instituíram as Comunidades Europeias e pelos Tratados, ou outros actos, que os modificaram"5 e pelos princípios gerais do direito ${ }^{6}$, definidos como "regras jurídicas não escritas, comuns e aceitas pelos sistemas jurídicos dos Estados-membros, constituindo os suportes estruturais do sistema normativo". ${ }^{7}$ Dele fazem parte os Tratados instituidores, os protocolos adicionais, os atos de complementação e atos de adesão. Todos esses componentes formam um todo unitário que devem ser analisados em conjunto.

Os três tratados que estabeleceram a comunidade europeia são nomeados de Tratados instituidores. São os seguintes: o da CECA (Comunidade Europeia do Carvão e do Aço), também conhecido como Tratado de Paris $^{8}$, celebrado em 18 de abril de 1951; o da CEE (Comunidade Econômica Europeia) e o da CEEA (Comunidade Europeia de Energia Atômica ou EURATOM). Os dois últimos compõem o Tratado de Roma', de 25 de março de 1957. Esses Tratados, suas alterações e complementações são considerados fontes originárias do Direito da União Europeia ${ }^{10}$.

Outras fontes originárias da União Europeia são: 1) o Tratado de Bruxelas; 2) O Ato Único Europeu; 3) o Tratado de Maastrich ou Tratado da União Europeia; 4) o Tratado de Amsterdã, 5) o Tratado de Nice e 6) o Tratado de Lisboa.

A Convenção de Viena sobre o Direito dos Tratados entre Estados, de 1969, determina, em seu art. 31º, que, para efeitos de interpretação de um tratado, o contexto compreende, além do texto: 1) o preâmbulo e anexos incluídos, 2) qualquer acordo relativo ao tratado e que tenham sido celebrados entre as Partes quando da con-

5 QUADROS, Fausto de. Direito da União Europeia. Coimbra: Almedina, 2004. p. 343.

6 QUADROS, Fausto de. Direito da União Europeia. Coimbra: Almedina, 2004. p. 184-186.

7 DROMI, José Roberto; EKMEKDJIAN, Miguel Angel; RIVERA, Julio César. Derecho comunitario: sistemas de integración, régimen del Mercosur. Ciudad Argentina, 1995. p. 44.

8 Caducou em 23 de julho de 2002.

9 Atualmente conhecido como Tratado Sobre o Funcionamento da União Europeia.

10 Sobre a criação da comunidade Europeia, Cf. DUARTE, Maria Luísa. União Europeia: estática e dinâmica da ordem jurídica Eurocomunitária. Coimbra: Almedina, 2011. p. 40-111. clusão dos tratados, 3) qualquer instrumento estabelecido por uma ou mais Partes quando da conclusão do tratado e aceito pelas outras Partes como instrumento relativo ao tratado. Logo, todas essas partes dos tratados compõem o direito originário ${ }^{11}$.

Rui Manoel Moura Ramos explica que diversos outros tratados que fazem referência aos Tratados mencionados, sejam modificando-os ou complementando-os, também são considerados fontes primárias ${ }^{12}$.

A semelhança do que ocorre nos ordenamentos jurídicos nacionais, a União Europeia apresenta-se hierarquicamente estruturada. As fontes primárias constituem parâmetro material e formal de controle do direito secundário.

\subsubsection{Os direitos fundamentais como fonte pri- mária}

Os Tratados Instituidores da União Europeia foram silentes quanto à proteção dos direitos fundamentais. Embora a inclusão desses direitos tenha sido objeto de discussão na fase de elaboração dos projetos de Tratados Institutivos ${ }^{13}$, a versão final aprovada não consagrou esses direitos nos atos jurídicos constitutivos das Comunidades Europeias.

Porém, fato é que o direito da União Europeia nunca passou ao largo dos direitos fundamentais, tanto assim o é que o Ato Único Europeu "inscreveu no preâmbulo da matriz institutiva das Comunidades Europeias ${ }^{14}$, uma fórmula genérica de declaração de direitos ${ }^{15}$ ", ao subscrever que os Estados-membros comprometem-se:

\begin{abstract}
A promover conjuntamente a democracia, com base nos direitos fundamentais reconhecidos nas constituições e legislações dos Estados-membros, na Convenção de protecção dos Direitos do Homem e das Liberdades Fundamentais e na Carta Social Europeia, nomeadamente, a liberdade, a igualdade e a justiça social.
\end{abstract}

11 CAMPOS, João da Mota. Manual de direito comunitário. 3. ed. Lisboa: Fundação Caloute Gulbenkian, 2002. p. 183.

12 RAMOS, Rui Manoel Moura. Das comunidades à União Europeia. Coimbra: Coimbra, 1994. p. 72-73

13 ZULEEG, Manfred. Fundamental rights and the law of the European Communities. Common Mkt. L. Rev. v. 8, p. 446 et seq. 1971.

14 DUARTE, Maria Luísa. Estudos de direito da União e das Comunidades Europeias, II. Coimbra: Coimbra, 2006. p. 210

15 DUARTE, Maria Luísa. Estudos de direito da União e das Comunidades Europeias, II. Coimbra: Coimbra, 2006. p. 210. 
Porém, apesar disso, o Tribunal de Justiça da União Europeia (TJUE), numa primeira fase, foi positivista, no que se refere às normas que deveria aplicar e dogmático na defesa do primado do direito comunitário em situação de conflito com o direito nacional, fase essa que Maria Luísa Duarte designa como "agnosticismo valorativo"16. Nessa fase, o Tribunal de Justiça compreendia que se o direito comunitário prevalecia sobre o direito nacional, isso implicava a prevalência sobre todas as normas constitucionais, mesmo as relativas aos direitos fundamentais. Durante o período agnóstico, o Tribunal de Justiça elege a "natureza absoluta e incondicional do primado sobre qualquer norma constitucional ou internacional garantidora de direitos fundamentais", ${ }^{17}$ sendo uma referência para esse período os casos Stork ${ }^{18}$ e o Consórcio de Carvão do Ruhr ${ }^{19}$. Nessa fase, os valores pelos quais o TJUE se orientou foram apenas o da liberdade de mercado e o da concorrência.

Fato é que o não-reconhecimento dos direitos fundamentais como fonte do direito da Comunidade Europeia suscitou nos tribunais constitucionais, nomeadamente, o alemão e o italiano, uma legitimidade para submeter os atos comunitários, a serem aplicados em seu território, a um controle de constitucionalidade no qual prevaleciam os direitos fundamentais, sob a justificativa de que a transferência de soberania para a União Europeia não podia configurar em diminuição dos direitos dos particulares.

O Tribunal de Justiça viu-se confrontado por alguns tribunais constitucionais e percebeu o risco do agnosticismo valorativo para a supremacia do direito da União Europeia, uma vez que os atos comunitários para serem aplicados nos territórios nacionais estavam sendo submetidos, quando do controle dos tribunais nacionais, ao parâmetro dos direitos fundamentais. Assim, o Tribunal de Justiça viu-se na necessidade "de enunciar um princípio geral de submissão das instituições comunitárias aos direitos fundamentais" ${ }^{20}$.

16 DUARTE, Maria Luísa. Estudos de direito da União e das Comunidades Europeias, II. Coimbra: Coimbra, 2006. p. 196.

17 DUARTE, Maria Luísa. Estudos de direito da União e das Comunidades Europeias, II. Coimbra: Coimbra, 2006. p. 37.

18 UNIÃO EUROPÉIA. Tribunal de Justiça. Acórdão TJUE de 04 de Fevereiro de 1959, Stork, Proc 01/58, Col. 1959, p. 293.

19 UNIÃO EUROPÉIA. Tribunal de Justiça. Acórdão TJUE de 13 de Maio de 1962, Consórcio de Carvão do Ruhr, Proc 13/60, Col. 1962 , p. 307.

20 MOREIRA, Vital. O tempo e a transposição de diretivas no direito da União Europeia. In: ESTUDOS em homenagem a Miguel Galvão Teles. Coimbra: Almedina, 2012. v. 1. p. 717-745.
O acórdão Stauder ${ }^{21}$ foi o marco inicial dessa segunda fase da jurisprudência do Tribunal de Justiça, pois, a partir desse caso, o Tribunal de Justiça integra os direitos fundamentais aos princípios gerais de Direito Comunitário, cujo respeito passa a ser observado pelo próprio Tribunal.

O caso Stauder refere-se a um beneficiário de uma pensão de guerra que considerou um atentado à sua dignidade pessoal e ao princípio da igualdade o fato de ter de se identificar para poder comprar manteiga a preço reduzido. Embora o Tribunal de Justiça tenha começado por considerar que, de acordo com as disposições comunitárias, não era obrigatória a identificação e que por isso se tornava desnecessário examinar o modo como o direito fora violado, acabou por reconhecer que o respeito pelos direitos fundamentais fazia parte dos princípios gerais da ordem jurídica comunitária e que lhe competia fazê-los respeitar. O Tribunal reconheceu assim, pela primeira vez, a existência de um regime autônomo de direitos fundamentais na União Europeia.

A jurisprudência iniciada no acórdão Stauder foi confirmada no caso Internationale Handelsgesellschaft ${ }^{22}$. Nesse Acórdão, o TJUE afirma que "a salvaguarda dos direitos fundamentais, inspirando-se nas tradições comuns aos Estados-membros, deve ser assegurada no quadro, na estrutura e nos objectivos da Comunidade ${ }^{23}$."

A primeira fonte invocada para esse novo princípio geral de direito comunitário foram as tradições constitucionais comuns aos Estados-membros. Porém, em 1974, o Tribunal de Justiça inaugurou uma nova fase e acrescentou às fontes os instrumentos internacionais de direitos humanos de que os Estados-membros eram partes, sendo que os Estados-membros eram partes da Convenção Europeia de Salvaguarda dos Direitos do Homem. No ano seguinte, o TJUE incluiu a Convenção de Roma de $1950^{24}$.

21 UNIÃO EUROPÉIA. Tribunal de Justiça. Acórdão TJUE de 12 de Novembro de 1960, Stauder, Proc 26/69, Rec 1969, p. 419.

22 UNIÃo EUROPÉIA. Tribunal de Justiça. Acórdão TJUE de 12 de Dezembro de 1970, Internacionalde Handelsgesellschaft, Proc 11/70, Rec. 1970 , p. 1125.

23 UNIÃO EUROPÉIA. Tribunal de Justiça. Acórdão TJUE de 12 de Dezembro de 1970, Internacionalde Handelsgesellschaft, Proc 11/70, Rec. 1970, p. 1125.

24 MOREIRA, Vital. O tempo e a transposição de diretivas no direito da União Europeia. In: ESTUDOS em homenagem a Miguel Galvão Teles. Coimbra: Almedina, 2012. v. 1. p. 717-745. 
O caso Nold $\mathrm{II}^{25}$ inaugura essa terceira fase supramencionada na jurisprudência comunitária, que se qualifica pela determinação de um critério materialmente amplo de direitos fundamentais ${ }^{26}$. Assim, passam a integrar o bloco normativo da União Europeia os direitos fundamentais consagrados nas tradições constitucionais comuns, nas constituições dos Estados-membros e nos instrumentos internacionais relativos aos Direitos do Homem, aos quais os Estados-membros tenham aderido ou cooperado. Esses direitos devem ser garantidos pelo Juiz comunitário em cooperação com os tribunais nacionais ${ }^{27}$.

Nessa fase, os direitos fundamentais, com especial destaque para os previstos na Convenção Europeia de Salvaguarda dos Direitos do Homem e das Liberdades Fundamentais, devem ser compatibilizados ao direito da União Europeia. Porém, não compete à União Europeia examinar a compatibilidade de uma lei nacional, que se situa num âmbito da competência do legislador nacional, com a Convenção Europeia. ${ }^{28}$ Dessa forma, o Tribunal de Justiça passa a resolver seus casos interpretando o direito comunitário à luz das disposições da Convenção Europeia de Direitos Humanos, chegando até mesmo a anular atos comunitários com fundamento na violação de normas da CEDH.

Nessa nova fase, o Tribunal de Justiça considera-se competente para apreciar a compatibilidade com a Convenção Europeia dos Direitos do Homem de quaisquer atos normativos dos Estados-membros que apresentem um elemento de conexão com o direito Comunitário ${ }^{29}$. Assim, ganha relevo o critério da "adequação funcional”, uma vez que a União Europeia, por força do princípio da atribuição, encontra-se limitada no seu âmbito de atuação. Sobre o tema discorre Maria Luísa Duarte:

O critério da "adequação funcional" tem, quanto a nós, um duplo alncance: 1) determinados direitos não integram o bloco de supra-legalidade comunitária e não são invocáveis como parâmetro de apreciação da validade dos actos comunitários pela razão singela que as Comunidades Europeias

25 UNIÃO EUROPÉIA. Tribunal de Justiça. Acórdão TJUE de 14 de Maio de 1974, Nold II, Processo 4/73, Rec. 1974, p. 491.

26 DUARTE, Maria Luísa. Estudos de direito da União e das Comunidades Europeias, II. Coimbra: Coimbra, 2006. p. 213.

27 DUARTE, Maria Luísa. Estudos de direito da União e das Comunidades Europeias, II. Coimbra: Coimbra, 2006. p. 213.

28 UNIÃO EUROPÉIA. Tribunal de Justiça. Acórdão TJUE de 11 de Julho de 1985, Cinètheque, Procs. 60 e 61/84, Col. 1985, p. 2605.

29 UNIÃO EUROPÉIA. Tribunal de Justiça. Acórdão TJUE de 25 de Outubro de 1975, Rutili, Processo 36/75, Col. 1975, p. 415. não poderão, no quadro dos seus poderes, adoptar comportamentos potencialmente contrários a tais direitos - v.g., o direito à vida ou o direito de contrair casamento. A integração material do direito fundamental invocado na ordem jurídica comunitária pressupõe uma avaliação de seu conteúdo garantístico à luz dos fins e objectivos das Comunidades; 2) por outro lado, a invocação de certos direitos, junto dos tribunais nacionais ou junto dos tribunais comunitários, a título de princípios gerais do Direito como fundamento de um juízo de desvalor sobre a legislação nacional aplicável só é procedente na exacta medida em que a matéria regulada pelo decisor nacional integra o âmbito material de aplicação do direito Comunitário ${ }^{30}$.

$\mathrm{Na}$ verdade, a invocação da $\mathrm{CEDH}$ tornou-se tão frequente e dominante na jurisprudência do TJUE que "o Tribunal passou a invocar diretamente os diversos direitos da Convenção como se fossem fonte direta ${ }^{31}$ ". Maria Luísa Duarte ${ }^{32}$ aduz que o Tribunal de Justiça literalmente "apropriou-se" do direito da Convenção. O seu entendimento é reforçado por Luís Pedro Cunha, ${ }^{33}$ que segundo ele, para o Tribunal, as disposições da Convenção, no âmbito do Direito Comunitário, fazem parte do ordenamento jurídico comunitário. Em suma, como sintetiza Vital Moreira, "muito antes da adesão formal verificou-se uma adesão jurisprudencial" ${ }^{34}$.

Essa jurisprudência foi sendo sucessivamente confirmada e desenvolvida pelo TJUE. Os princípios nela consagrados foram, posteriormente, incluídos nos Tratados pela via da revisão ${ }^{35}$. Como explica Maria Luísa Duarte, o grande salto para a consagração dos direitos fundamentais ocorreu com o Tratado de Maastricht, em virtude de duas declarações fundamentais: a vinculação da União Europeia aos direitos fundamentais $\left(\operatorname{art.~} 6^{\circ}\right.$ ) e

30 DUARTE, Maria Luísa. Estudos de direito da União e das Comunidades Europeias, II. Coimbra: Coimbra, 2006. p. 214.

31 MOREIRA, Vital. O tempo e a transposição de diretivas no direito da União Europeia. In: ESTUDOS em homenagem a Miguel Galvão Teles. Coimbra: Almedina, 2012. v. 1. p. 717-745.

32 DUARTE, Maria Luísa. União Europeia e direitos fundamentais. Lisboa, 2006. p. 106.

33 CUNHA, Luís Pedro. Considerações sobre a possibilidade de adesão da comunidade à Convenção Europeia dos Direitos do Homem. Gestão e Desenvolvimento, v. 2, p. 35-52, 1993. Disponível em: $<$ http://www.estig.ipeja.pt/ ac_direito/gestaododesenvolvimento2_35.pdf $>$. Acesso em: 24 ago. 2013.

34 MOREIRA, Vital. O tempo e a transposição de diretivas no direito da União Europeia. In: ESTUDOS em homenagem a Miguel Galvão Teles. Coimbra: Almedina, 2012. v. 1.

35 MARTINS, Ana Maria Guerra. Constitucionalismo Europeu e direitos fundamentais após o Tratado de Lisboa. Instituto de Ciência JurídicoPoliticas. Disponível em: <http:// www.icjp.pt/sites/default/files/ media/822-1351.pdf>. Acesso em: 14 ago. 2013. 
a previsão de um estatuto da cidadania da União, reconhecido a todos os cidadãos dos Estados-membros ${ }^{36}$. O Tratado de Amsterdã, de 1997, complementou o Tratado da União Europeia e conferiu ao TJUE o poder de fiscalizar a ação das instituições comunitárias à luz dos direitos fundamentais ${ }^{37}$. Como esclarece Vital Morei$\mathrm{ra}^{38}$, o mesmo Tratado garantiu ainda que os direitos e liberdades fundamentais descritos no Tratado de Maastrich fossem critério de conduta dos Estados-membros, podendo o Estado ser sancionado em caso de "violação grave e persistente ${ }^{39}$ '.

Contudo, essas modificações, uma vez que não dotaram a União Europeia de um catálogo de Direitos Fundamentais, não foram suficientes para garantir a aplicação do instituto, cabendo ao Juiz da União Europeia a definição de um modelo de tutela dos direitos fundamentais ${ }^{40}$.

O Tratado de Lisboa representou um novo passo para a proteção dos direitos fundamentais na União Europeia. O novo artigo sobre os direitos fundamentais $\left(\operatorname{artigo~} 6^{\circ}\right)$ inscrito no TUE dispõe que a Carta dos Direitos Fundamentais da União Europeia é vinculativa na atuação dos órgãos e Estados-Membros da UE, desde que estes apliquem e executem o direito da União. No entender de Ana Maria Guerra Martins ${ }^{41}$ duas são as principais inovações do Tratado: 1) a equiparação do valor jurídico da Carta dos Direitos Fundamentais da União Europeia (CDFUE) ao dos Tratados; e 2) a atribuição de competência da União Europeia para aderir à $\mathrm{CEDH}$. Assim, a partir desse momento, a União Europeia passa a gozar de um catálogo de direitos fundamentais, o que contribui para o reforço da vertente constitucional da União Europeia.

Assim, em matéria de direitos fundamentais, a União Europeia passa a estar vinculada, formalmente, à Carta de Direitos Fundamentais, que é equiparada à mes-

36 DUARTE, Maria Luísa. União Europeia e direitos fundamentais. Lisboa, 2006. p. 211.

37 TCE, art. 46, d.

38 MOREIRA, Vital. O tempo e a transposição de diretivas no direito da União Europeia. In: ESTUDOS em homenagem a Miguel Galvão Teles. Coimbra: Almedina, 2012. v. 1.

39 Art. $7^{\circ}$ do TUE.

40 DUARTE, Maria Luísa. União Europeia e direitos fundamentais. Lisboa, 2006. p. 211.

41 MARTINS, Ana Maria Guerra. Constitucionalismo Europeu e direitos fundamentais após o Tratado de Lisboa. Instituto de Ciência JurídicoPoliticas. Disponível em: <http:// www.icjp.pt/sites/default/files/ media/822-1351.pdf>. Acesso em: 14 ago. 2013. ma força jurídica dos Tratados. Além disso, o Tratado de Lisboa possibilitou que a União Europeia venha a aderir à Convenção Europeia dos Direitos do Homem (CEDH) e ao sistema de garantia assegurado pelo Tribunal Europeu de Direitos do Homem ${ }^{42}$. Porém, fato é que essas alterações não acarretaram maiores alterações na jurisprudência do Tribunal de Justiça, pelo menos no curto prazo, pois, como aqui demonstrado, o Tribunal já reconhecia o status de fonte primária aos direitos fundamentais, antes mesmo da sua formalização.

\subsection{Fontes secundárias}

As fontes secundárias são constituídas pelas normas criadas pelos órgãos da União Europeia, de acordo com os respectivos parâmetros materiais e formais descritos no direito originário. As fontes do direito secundário estão positivadas no art. $288^{\circ}$ do Tratado Sobre o Funcionamento da União Europeia (TFUE), são elas: os regulamentos, as diretivas, as decisões, as recomendações e os pareceres.

Os três primeiros podem ser atos legislativos ou não legislativos, atos delegados e de execução. Na verdade, enquanto atos jurídicos vinculativos, esses três atos podem referir-se às disposições jurídicas de carácter geral e abstrato, bem como medidas concretas e individuais. Significa isto que esses atos suportam, formalmente, o exercício de funções materialmente legislativas ou executivas.

Assim, para o desempenho das suas atribuições e nos termos do TFUE, o Parlamento Europeu em conjunto com o Conselho, o Conselho e a Comissão adotam regulamentos e diretivas, tomam decisões e formulam recomendações ou pareceres.

As instituições da União apenas podem adotar as fontes secundárias se uma disposição dos Tratados lhes conferir poder para tanto. O princípio da atribuição, que rege a delimitação das competências da UE, está expressamente consagrado no artigo $5^{\circ}, n^{\circ} 1$, do Tratado da União Europeia (TUE). Todavia, o princípio da atribuição encontra exceção no art. 352 do TFUE que prevê cláusula de competência subsidiária ${ }^{43}$.

42 DUARTE, Maria Luísa. União Europeia: estática e dinâmica da ordem jurídica Eurocomunitária. Coimbra: Almedina, 2011. p.80.

$43 \mathrm{O}$ artigo $352 .^{\circ}$ do Tratado sobre o Funcionamento da União Europeia (TFUE) prevê uma cláusula de flexibilidade relativa aos domínios de competência da União Europeia. Esta cláusula permite 
Os processos legislativos (fonte secundária) podem ser ordinários ou especiais. Por meio desses processos legislativos são aprovados regulamentos, diretivas e decisões. São os tratados que determinam os casos que serão regulamentados pelo processo legislativo ordinário e especial.

Além disso, o Tratado de Lisboa introduz "cláusulas-ponte". Essas cláusulas permitem generalizar, em determinadas condições, o processo legislativo ordinário a domínios inicialmente não abrangidos pelo seu âmbito de aplicação ${ }^{44}$.

\subsubsection{Os regulamentos}

Os regulamentos têm caráter geral e são diretamente aplicáveis e obrigatórios em todos os Estados-membros, sem a necessidade de expedição de atos de transposição para que produzam efeitos no ordenamento jurídico nacional de determinado Estado-membro. Calogero Pizzolo ressalta o alcance geral desses atos, ou seja, sua capacidade de gerar direitos e obrigações aos Estados-membros e aos particulares, bem como a sua aplicabilidade direta, que constitui a possibilidade desses direitos e obrigações serem garantidos pelas jurisdições nacionais. ${ }^{45}$

Os regulamentos estabelecem regras, impõem obrigações ou conferem direitos a todos que se incluam ou passem a incluir na categoria de seus destinatários. ${ }^{46}$ As características gerais dos regulamentos são: o caráter geral; a natureza obrigatória; e o fato de gozarem de aplicabilidade direta na ordem interna dos Estados-

ajustar as competências da União aos objetivos previstos pelos Tratados, sempre que estes últimos não prevejam os poderes necessários para atingir os referidos objetivos.

44 "Por seu lado, uma certa rigidez do princípio da tipicidade poderá ser compensada pela via da activação das cláusulas-passarela. Em vez de uma revisão formal dos Tratados, bastará uma decisão do Conselho Europeu, adoptada por unanimidade, sem oposição dos parlamentos nacionais, para adaptar a fórmula procedimental de decisão em certo domínio, no sentido de passar a decidir por maioria qualificada onde antes se exigia a unanimidade ou no sentido de aplicar o procedimento legislativo ordinário em subsitituição do procedimento legislativo especial (v. artigo $48^{\circ}, n^{\circ} 7$, UE)." DUARTE, Maria Luísa. União Europeia: estática e dinâmica da ordem jurídica Eurocomunitária. Coimbra: Almedina, 2011. p. 296.

45 PIZZOLO, Calogero. Globalizacion e integration: integración: ensayo de una teoría general: Comunidad Andina, Mercosur, Unión Europea, SICA. Buenos Aires: Ediar, 2002. p. 117

46 CAMPOS, João da Mota. Manual de direito comunitário. 3. ed. Lisboa: Fundação Caloute Gulbenkian, 2002. p. 303.
- membros $^{47}$.

Embora Fausto de Quadros conceitue o regulamento como ato legislativo, ele próprio chama a atenção para o fato de que existem outras modalidades de regulamento que não se enquadram nessa categoria, é o caso do regulamento de execução ou de aplicação, que é hierarquicamente subordinado ao regulamento de base (ato legislativo).

Desta forma, claro está que os regulamentos da União Europeia gozam de efeito direto vertical, uma vez que podem ser invocados nas relações entre particulares e Estado, bem como de efeito direto horizontal, na medida em que podem ser invocadas nas relações de paridade jurídica entre os particulares.

\subsubsection{A decisão}

A decisão é ato vinculativo, logo, é obrigatória em todos os seus elementos para os destinatários que designar, está prevista no art. 288, \ $4^{\circ}$ do TFUE. Caso a decisão se dirija aos particulares, implicará direitos e obrigações relativamente a seus destinatários e constituirá título executivo, aplicando-se diretamente na ordem interna, uma vez que não requer legislação de transposição para vigerem no ordenamento jurídico de um Estado-membro. "A decision of the Council or Commission, being an individual act, is addressed to specified persons, either states or individuals. As it is legally binding, it requires no further implementation" ${ }^{\prime 4}$.

João Mota de Campos ensina que a decisão é ato unilateral da Comunidade, é emanada de autoridade supranacional e é obrigatória para os destinatários nela designados. Tem, em regra, o objetivo de prescrever condutas a Estado-membro, indivíduo ou empresa em torno de determinado caso particular ${ }^{49}$.

A decisão que se dirige aos particulares ou às empresas pode ser invocada diretamente pelo favorecido, uma vez que não é necessário recorrer à teoria do efeito direto. A mesma solução já encontra alguma dificuldade

47 QUADROS, Fausto de. Direito da União Europeia. Coimbra: Almedina, 2004. p. 354.

48 A decisão do Conselho ou da Comissão, quando for um ato individual, é dirigida a determinadas pessoas, sejam elas estados ou indivíduos. Como é juridicamente vinculativa, não requer atos de transposição. KENT, Penelope. Law of the European Union. 2. ed. London: M\&E Pitman Publishion, 1996. p. 27, tradução nossa.

49 CAMPOS, João da Mota. Manual de direito comunitário. 3. ed. Lisboa: Fundação Caloute Gulbenkian, 2002. p. 305. 
de ser aplicada quando a decisão se dirigir aos Estados-membros, pois, nesse caso, poder-se-ia defender que só as medidas nacionais seriam susceptíveis de modificar a situação jurídica dos particulares ${ }^{50}$.

Porém, apesar do art. $288^{\circ}$ do TFUE não prever o efeito direto para as decisões, fato é que mesmo quando dirigidas aos Estados-membros elas gozam de aplicabilidade direta. Nem poderia ser de outra forma, uma vez que a medida é necessária para garantir a sua eficácia no cumprimento das funções referidas. Por isso, o TJUE, desde o Acórdão Franz Grad ${ }^{51}$, entende que as decisões não carecem de qualquer ato de transposição nacional, valendo por si mesmas no ordenamento jurídico interno dos Estados-membros, como título executivo ${ }^{52}$.

\subsubsection{Recomendações e Pareceres}

Já as recomendações e pareceres não são vinculativos, o que, entretanto, não os torna irrelevantes ou desprovidos de efeitos jurídicos. Os pareceres são "declarações unilaterais manifestadas de forma interna ou entre os órgãos comunitários, no exercício de funções administrativas, produzindo efeitos de forma indireta ${ }^{53}$ ". Possuem, assim, uma função de orientar comportamentos.

As recomendações podem ser dirigidas para uma autoridade da União Europeia ou aos Estados-membros. Elas refletem opiniões sobre determinados assuntos e podem prescrever procedimentos que os Estados-membros devem observar. Assim, o juiz nacional deve levar a recomendação em consideração no momento de decidir sobre norma afeta ao direito da União Europeia, dada a sua função hermenêutica.

Os pareceres não são vinculantes, mas podem criar condições prévias à formulação de atos jurídicos vinculantes. Têm também valor interpretativo na leitura de atos vinculates, como aliás, reconheceu o TJUE no Acórdão Salvatore Grimaldi ${ }^{54}$. Além disso, podem

50 MARTINS, Ana Maria Guerra. Curso de direito constitucional da União Europeia. Coimbra: Almedina, 2004. p. 398.

51 UNIÃO EUROPÉIA. Tribunal de Justiça. Acórdão TJUE de 06 de Outubro de 1970, Franz Grad, Proc. 9/70, Rec. 1970, p. 825.

52 MARTINS, Ana Maria Guerra. Curso de direito constitucional da União Europeia. Coimbra: Almedina, 2004. p. 398.

53 ALMEIDA, Elizabeth Accioly Pinto de. Mercosul e União Européia: estrutura jurídico-institucional. Curitiba: Juruá, 2004. p. 96

54 UNIÃO EUROPÉIA. Tribunal de Justiça. Acórdão TJUE de 13 de Dezembro de 1988, proferido no Proc. 322/88, Salvatore Grimaldi v. Fonds, Col. 1989, p. 4407. constituir pressuposto prévio necessário à propositura de uma ação no TJUE. Por outro lado, o eventual não acatamento das recomendações poderá determinar a adoção de um ato vinculativo, produzindo, por isso, um efeito jurídico mesmo que não vinculativo ${ }^{55}$.

\subsubsection{Diretivas}

As diretivas ${ }^{56}$ vinculam os Estados-Membros quanto aos objetivos a serem alcançados dentro de um determinado prazo, deixando, no entanto, às instâncias nacionais a competência quanto à forma e aos meios a utilizar. As diretivas têm de ser transpostas para o direito interno de cada país de acordo com os seus procedimentos específicos. São atribuídas às diretivas quatro qualidades jurídicas, segundo Calogero Pizzolo ${ }^{57}$ : 1) não têm alcance geral; 2) obrigam quanto ao seu resultado; 3) os Estados-membros têm liberdade para eleger os meios de alcançá-los e 4) não possuem efeito direto.

Segundo Penelope Kent, A diretiva vincula o resultado a ser obtido pelo Estado-membro destinatário, porém, ela permite que os Estados-membros escolham, livremente, a forma que os atos serão implementados no direito interno, seja por meio de alterações legislativas ou administrativas. A diretiva pode ser dirigida a alguns ou a todos os Estados-membros e é utilizada como medida de harmonização ${ }^{58}$.

Rosemiro Pereira Leal ensina que a diretiva é considerada meio de produção normativa ontologicamente incompleta, pelo fato de apenas determinar resultados, sem especificar os meios. Por isso, estabelecem uma cooperação entre a Comunidade e os Estados-membros, ao permitir certa autonomia para que seja atingido o resultado pretendido ${ }^{59}$.

55 CUNHA, Ricardo Sousa da. Introdução diacrónica e incrónica ao direito da União Europeia. Disponível em: < https://woc.ipca.pt/esg/ getFile.do?tipo $=2 \&$ id $=7633 \square>$. Acesso em: 03 ago. 2013.

56 Sobre o tema, Cf. BARRIONUEVO, María Bellido. La directiva comunitária. Madrid: Dykinson, 2003; e PRECHAL, Sacha. Directives in European Community law. Oxford: Clarendon, 1995.

57 PIZZOLO, Calogero. Globalizacion e integration: integración: ensayo de una teoría general: Comunidad Andina, Mercosur, Unión Europea, SICA. Buenos Aires: Ediar, 2002. p. 136

58 KENT, Penelope. Law of the European Union. 2. ed. London: M\&E Pitman Publishion, 1996. p. 26-27, tradução nossa. No mesmo sentido: QUADROS, Fausto de. Direito da União Europeia. Coimbra: Almedina, 2004. p. 354, e CAMPOS, João Luiz Mota. Manual de direito europeu: o sistema institucional, a ordem jurídica e ordenamento económico da União Europeia. 6. ed. Coimbra: Coimbra, 2010. p. 325.

59 LEAL, Rosemiro Pereira. Curso de direito econômico comunitário. 
Excepcionalmente, a jurisprudência da União Europeia admite a aplicação direta da diretiva, desde que alguns requisitos sejam cumpridos, o assunto será aprofundando nos próximos capítulos, mas essa possibilidade de aplicação direta decorre do fato de que se os Estados-membros não transpuserem a diretiva nos prazos nela previstos, ou na inexistência de prazo, em tempo útil, os particulares ficarão desprovidos e em desigualdade de circunstância, por força de um descumprimento imputável ao Estado-membro. Assim, para impedir essa situação no qual o Estado estaria prejudicando os particulares e, muitas vezes, impedindo que esses particulares invocassem os direitos consagrados nas diretivas em face desse mesmo Estado que se encontra em mora, a diretiva pode ser diretamente aplicável, com o intuito de proteger o cidadão contra a inércia estatal ${ }^{60}$.

A diretiva da União é oriunda da diretiva do Direito Administrativo francês, onde ela serve de instrumento para o superior hierárquico orientar o subalterno no exercício de poderes discricionários ${ }^{61}$. Não é um ato de alcance geral, uma vez que obriga apenas os destinatários que ela própria designa. Esses destinatários são: o Estado, todos os Estados-membros, alguns deles ou um único ${ }^{62}$.

São duas as finalidades predominantes de uma diretiva: a primeira está prevista nos Tratados, refere-se à concretização do programa de liberalização da circulação; a segunda é a harmonização das ordens jurídicas nacionais com o direito da União ${ }^{63}$. É justamente essa última finalidade que lhe confere a natureza de norma, similar ao regulamento, como já foi reconhecido pelo Tribunal de Justiçą ${ }^{64}$. Além disso, o fato de os destinatários serem determináveis, por si só, não lhe retira o caráter geral e abstrato ${ }^{65}$.

A diretiva é vista como instrumento de harmonização de legislações pelo fato da realização dos objetivos

Porto Alegre: Síntese, 2002. p. 57

60 MARTINS, Ana Maria Guerra. Curso de direito constitucional da União Europeia. Coimbra: Almedina, 2004. p. 397.

61 QUADROS, Fausto de. Direito da União Europeia. Coimbra: Almedina, 2004. p. 358.

62 CAMPOS, João Luiz Mota. Manual de direito europeu: o sistema institucional, a ordem jurídica e ordenamento económico da união europeia. 6. ed. Coimbra: Coimbra, 2010. p. 326.

63 QUADROS, Fausto de. Direito da União Europeia. Almedina, 2004. p. 358

64 UNIÃo EUROPÉIA. Tribunal de Justiça. Acórdão TJUE de 22 de fevereiro de 1984, Kloppenburg, Proc. 70/83, Col., p. 1075.

65 UNIÃO EUROPÉIA. Tribunal de Justiça. Acórdão TJUE de 27 de abril de 1989, Comissão c. Itália, Proc. 324/87, Col., p. 1013 e ss. atribuídos à União implicar, muitas vezes, que ela tenha que intervir, legislando, de maneira acessória, nos temas que considera indispensáveis. Quando a matéria a ser legislada necessitar ser uniforme, a União atua por meio dos regulamentos. Porém, nos demais casos, quer por limitação explícita imposta pelo Tratado, quer em respeito ao princípio da proporcionalidade, a União atua por meio das diretivas ${ }^{66}$.

As diretivas proporcionam às instituições da União uma maior flexibilidade, ao contrário do que ocorre com os regulamentos que são um rígido instrumento de uniformização jurídica. As diretivas atendem às particularidades nacionais, uma vez que deixam aos Estados-membros uma certa margem de manobra para a implementação das regras adotadas pela União, pelo fato de referirem-se a objetivos menos ambiciosos de aproximação das legislações ${ }^{67}$.

As diretivas são balizadas pelo princípio da subsidiariedade. O resultado, a finalidade ou o objetivo comum a atingir pelos Estados-membros deverá ser determinado pela União, pois nenhum Estado está em posição superior aos demais, logo, não será possível que os resultados sejam impostos unilateralmente por um determinado Estado aos demais Estados-membros. Porém, a realização desses objetivos deverá ser alcançada, em cada um, mediante a utilização das formas e dos meios que considerem mais convenientes e conforme a sua situação interna, econômica, social e jurídica ${ }^{68}$.

Ao contrário do regulamento, a diretiva não substitui qualquer ato normativo nacional, mas, sim, vincula o Estado-membro destinatário quanto ao resultado a alcançar, deixando para as autoridades nacionais o dever de estabelecer as formas e os meios para a norma viger. Percebe-se que a diretiva estabelece objetivos que deverão ser cumpridos pelo Estado destinatário no prazo estipulado ${ }^{69}$.

Da mesma forma que ocorre com os regulamentos, as diretivas também se dividem em diretivas de base e

66 GOMES, José Caramelo. Lições de direito da União Europeia. Coimbra: Almedina. 2011. p. 161.

67 CAMPOS, João Luiz Mota. Manual de direito europeu: o sistema institucional, a ordem jurídica e ordenamento económico da União Europeia. 6. ed. Coimbra: Coimbra, 2010. p. 325.

68 CAMPOS, João Luiz Mota. Manual de direito europeu: o sistema institucional, a ordem jurídica e ordenamento económico da União Europeia. 6. ed. Coimbra: Coimbra, 2010. p. 326.

69 GOMES, José Caramelo. Lições de direito da União Europeia. Coimbra: Almedina. 2011. p. 161. 
de execução, sendo que as de execução estão hierarquicamente subordinadas às de base.

\subsubsection{Transposição e efeitos jurídicos das diretivas}

Uma diretiva só vige na ordem interna dos Estados, após a sua transposição para o direito interno, no prazo por ela fixado. $\mathrm{O}$ ato de transposição não se assemelha ao de recepção ${ }^{70}$. A transposição de uma diretiva para ordem interna constitui uma obrigação dos Estados destinatários, devendo ela ser realizada no prazo e nos termos estipulados na própria diretiva. É necessário, ainda, que o Estado destinatário comunique, periodicamente, à Comissão as medidas que vão sendo adotadas para a execução das diretivas na ordem interna ${ }^{71}$.

O primeiro e mais evidente dos efeito jurídicos produzidos por uma diretiva é a obrigação resultante para os Estados-membros de concretizarem, no prazo nela estipulado, todas as medidas necessárias para assegurar a plena transposição dos seus comandos na ordem jurídica interna ${ }^{72}$.

Essa obrigação de transposição tem sido interpretada rigorosamente pelo Tribunal de Justiça, conforme jurisprudência uniforme oriunda da obrigação de cooperação. Assim, “cada Estado-membro destinatário de uma directiva deve tomar, no quadro da sua ordem jurídica nacional, todas as medidas necessárias para assegurar o pleno efeito da directiva, em conformidade com o objectivo geral por ela perseguido ${ }^{73}$ ".

O fato de uma diretiva se dirigir apenas aos Estados destinatário e depender de um ato de transposição para produzir efeitos no ordenamento jurídico interno de um Estado-membro, caracteriza uma distinção fundamental entre as diretivas e os regulamentos. Os regulamentos são atos supranacionais, exprimem uma relação de supremacia do direito da União sobre o direito interno. Ao contrário, as diretivas, por sua vez, carecem dessa supremacia, sendo um ato eminentemente de coope-

70 Cf. PEREIRA, André Gonçalves; QUADROS, Fausto de. Direito internacional público. 3. ed. Coimbra, 1993. p. 81-94.

71 QUADROS, Fausto de. Direito da União Europeia. Coimbra: Almedina, 2004. p. 359.

72 CRUZ VILAÇA, José Luís. A propósito dos efeitos das directivas na ordem jurídica dos Estados-membros. Justiça Administrativa, n. 30, p. 3-19, nov./dez. 2001.

73 UNIÃO EUROPÉIA. Tribunal de Justiça. Acórdão TJUE de 14 de Junho de 2001, Comissão/Italia, C-207/2000 apud CRUZ VILAÇA, José Luís. A propósito dos efeitos das directivas na ordem jurídica dos Estados-membros. Justiça Administrativa, n. 30, p. 3-19, nov./dez. 2001. ração entre a União e a ordem interna, sem prejuízo do princípio geral do primado do direito da União sobre o direito nacional ${ }^{74}$. Porém, apesar dessa ausência de subordinação, o Tribunal de Justiça já anotou que, durante o período de transposição, "os Estados devem abster-se de adoptar quaisquer medidas que possam comprometer o resultado prescrito pela respectiva directiva ${ }^{75}$, competindo aos tribunais nacionais controlar a legalidade das disposições nacionais ${ }^{76}$. Assim, percebe-se que a transposição não só obriga os Estados a aprovar todas as medidas internas que sejam necessárias para a implementação de uma diretiva, como também devem divulgar os direitos que elas conferem aos particulares e eliminar do direito interno todas as disposições que se mostrem incompatíveis com a aplicação da diretiva ${ }^{77}$.

As medidas internas de transposição de uma diretiva devem ter força jurídica suficiente para revogar as disposições nacionais incompatíveis com a diretiva ${ }^{78}$. Isso quer dizer que, uma vez que é de exclusiva responsabilidade do Estado escolher a forma do ato que irá transpor o conteúdo de uma diretiva para o direito interno, o Estado-membro não poderá, futuramente, esconder-se no grau hierárquico do ato de transposição, seja ele administrativo ou legislativo, com intuito de recusar o primado da diretiva transposta sobre o direito interno.

Caso o Estado destinatário não transponha a diretiva no prazo estipulado, ou caso os seus órgãos não cumpram o disposto na diretiva, ou mesmo nos casos de errada e insuficiente transposição, o Estado incorre em situação de não cumprimento, que pode resultar na abertura de processo, isso porque o prazo para a transposição tem caráter imperativo ${ }^{79}$.

É possível que o processo por não cumprimento seja substituído por uma ação de responsabilidade civil extracontratual a ser proposta contra o Estado faltoso

74 QUADROS, Fausto de. Direito da União Europeia. Coimbra: Almedina, 2004. p. 359.

75 UNIÃO EUROPÉIA. Tribunal de Justiça. Acórdão TJUE de 18 de Dezembro de 1997, Inter-Environnement, Proc. C-129/96, Col., p. I-411.

76 UNIÃO EUROPÉIA. Tribunal de Justiça. Acórdão TJUE de 25 de Maio de 1982, Comissão c. Países Baixos, Proc. 96/81, Col., p. 1791.

77 QUADROS, Fausto de. Direito da União Europeia. Coimbra: Almedina, 2004. p. 360.

78 UNIÃO EUROPÉIA. Tribunal de Justiça. Acórdão TJUE de 17 de Novembro de 1992, Comissão c. Irlanda, Proc. C-235/91, Col., p. I-5.917.

79 UNIÃO EUROPÉIA. Tribunal de Justiça. Acórdão TJUE de 6 de outubro de 1970, Franz Grad, Proc. 09/70, Rec. 1970, p. 825. 
nos seus tribunais nacionais, segundo as regras processuais próprias de cada Estado ${ }^{80}$. Porém, uma vez que se trata de responsabilidade pela não implementação de uma diretiva, os critérios para a reparação do dano são os determinados pelo direito da União. O regime aplicável nesse caso é o definido pelo Tribunal de Justiça na jurisprudência iniciada no caso Francovich ${ }^{81}$.

Depois de esgotado o prazo para a transposição de uma diretiva e, ainda assim, caso o Estado destinatário tenha permanecido inerte, a diretiva goza de efeito direto (caso reúna os requisitos necessários). Ou seja, ela pode ser invocada diretamente por um particular perante o Estado faltoso. O efeito direto afigura-se como uma sanção para o Estado pelo fato dele não ter cumprido a sua obrigação em tempo hábil ou a tenha feito de maneira incorreta, isso ocorre quando o Estado transpõe mal uma diretiva.

Fausto de Quadros ${ }^{82}$ chama atenção para o fato de que o efeito direto não afasta a responsabilidade extracontratual do Estado pelos prejuízos causados aos particulares, pela não transposição de uma diretiva dentro do prazo determinado ou, mesmo, pela sua transposição incorreta e indevida. Não afasta ainda o dever de o Estado efetivar a transposição da diretiva, mesmo que fora do prazo.

Existe uma relação direta entre a diretiva e o tempo $^{83}$. É a própria diretiva que disporá a partir de quando ela deve ser aplicada na ordem jurídica dos Estados-membros. A implementação de uma diretiva no direito interno de um Estado-membro ocorrerá, como ensina Maria Luísa Duarte ${ }^{84}$, por meio da "forma (por exemplo, ato legislativo ou ato regulamentar) e dos meios (por exemplo, aprovação de um quadro normativo específico ou revisão e adaptação de um quadro normativo avulso previgente) que o Estado-membro considerar mais adequado".

80 QUADROS, Fausto de. Direito da União Europeia. Coimbra: Almedina, 2004. p. 361.

81 QUADROS, Fausto de. Direito da União Europeia. Coimbra: Almedina, 2004. p. 362.

82 QUADROS, Fausto de. Direito da União Europeia. Coimbra: Almedina, 2004. p. 362.

83 Como observa Maria Luísa Duarte em: DUARTE, Maria Luísa. O tempo e a transposição de diretivas no direito da união europeia. In: ESTUDOS em homenagem a Miguel Galvão Teles. Coimbra: Almedina, 2012. v. 1. p. 423-439.

84 DUARTE, Maria Luísa. O Tempo e a Transposição de Diretivas no Direito da União Europeia. In: ESTUDOS em homenagem a Miguel Galvão Teles. Coimbra: Almedina, 2012. v. 1.
O prazo de transposição é fixado pela própria diretiva e começa a contar da entrada em vigor do ato (ou vigésimo dia seguinte ao da publicação, nos casos em que a diretiva for omissa ${ }^{85}$ ). Essa regra se aplica tanto para as diretivas que sejam atos não legislativos (de natureza delegada ${ }^{86}$ ou de execução), ${ }^{87}$ dirigidos a todos os Estados-membros. Contudo, caso a diretiva seja dirigida a um Estado-membro ou a determinado grupo de Estados-membros, a produção de efeitos inicia-se com a notificação dos Estados-membros destinatários da norma ${ }^{88}$.

Além disso, o Tribunal de Justiça já parametrizou ${ }^{89}$ os termos a ser seguidos pelas medidas nacionais de transposição, a fim de que o Tratado seja respeitados,. Em síntese: "As disposições de uma directiva devem ser postas em prática com uma eficácia vinculativa incontestável, com a especificidade, a exactidão e a clareza requeridas para que seja satisfeita a exigência de segurança jurídica." ${ }^{90}$

Portanto, o principal efeito de uma diretiva é gerar uma obrigação de transposição para o Estado-membro destinatário, sendo que os efeitos mediatos, por mais importantes que sejam, são acessórios. Disso decorre que, na eventualidade de uma diretiva produzir efeito direto, isso por si só, não possibilita, de modo algum, que o Estado-membro se exima à sua obrigação primordial de assegurar a transposição da respectiva diretiva. Caso assim não aja, a Comissão fica legitimada para intentar a ação de não cumprimento descrita no

85 Art. $297, \mathrm{n}^{\circ} 1, \mathrm{c} / \mathrm{c} 289^{\circ}, \mathrm{n}^{\circ} 1$, ambos do TFUE

86 Art. $290, \mathrm{n}^{\circ} 1$ do TFUE.

87 Art. $291, \mathrm{n}^{\circ} 4$ do TFUE.

88 Art. $297^{\circ}, \mathrm{n}^{\circ} 2$, parágrafo terceiro, do TFUE.

89 Cf. TJUE. Acórdão TJUE de 23 Abril de 1995, Comissão/Grécia, Proc. C-365/93, Col. 1995, p. I-499, no 9. "Se é verdade que a transposição de uma directiva não exige necessariamente uma acção legislativa de cada Estado-membro, é contudo indispensável que o direito nacional em causa garanta efectivamente a plena aplicação da directiva, que a situação jurídica decorrente deste direito seja suficientemente precisa e clara e que aos beneficiários seja dada a possibilidade de conhecerem a plenitude dos seus direitos e, sendo o caso disso, de os invocarem perante os tribunais nacionais. Ver ainda UNIÃO EUROPÉIA. Tribunal de Justiça. Acórdão de 21 de Junho de 2001, Comissão/Luxemburgo, C-119/2000 apud CRUZ VILAÇA, José Luís. A propósito dos efeitos das directivas na ordem jurídica dos Estados-membros. Justiça Administrativa, n. 30, p. 3-19, nov./dez. 2001. "Nenhum Estado-membro pode invocar disposições, práticas ou situações da sua ordem jurídica interna para justificar a inobservância das obrigações e dos prazos prescritos por uma directiva". 90 UNIÃO EUROPÉIA. Tribunal de Justiça. Acórdão TJUE de 19 de maio de 1999, Comissão/França, C-225/97, Rec. I-3011, nº 37. 
art. $226^{\circ}$ do Tratado $^{91}$.

Na expressão do Tribunal de Justiça, o direito de invocar o efeito direto constitui apenas uma garantia mínima para os particulares, decorrentes do caráter vinculativo das obrigações impostas aos Estados-membros por força das diretivas ${ }^{92}$.

O Tribunal de Justiça, ainda, tem decidido que, desde o momento da entrada em vigor da diretiva, nasce uma obrigação para os Estados de coibirem-se de praticar qualquer ato que possa prejudicar a plena transposição da diretiva e a entrada em vigor do regime por ela pretendido $^{93}$.

Todavia, a questão que permanece em discussão é o alcance desta obrigação de boa-fé, isto é, qual é o limite dessa proibição? Em suma: o Estado-membro está proibido de aprovar qualquer ato que seja contrário ao regime pretendido pela diretiva, durante o período de transposição ou se a boa-fé apenas limita o direito de o Estado de criar regimes que impeçam em absoluto a entrada em vigor do regime pretendido pela diretiva?

Uma possível resposta às questões acima descritas surgiu no caso Wallonie ${ }^{94}$. O Tribunal de Justiça, ao analisar o princípio da lealdade combinado com o art. $18^{\circ}$ da Convenção de Viena sobre o Direito dos Tratados, concluiu que durante o período de transposição o Estado-membro está vedado de "adotar disposições suscetíveis de comprometer seriamente o resultado prescrito na diretiva," $" 95$ ou seja, o Estado-membro não pode agir de forma contrária à diretiva, emitindo atos legislativos ou regulatórios que dificultem ou contrariem a diretiva que se encontra em período de transposição, ou seja, não é que os particulares tenham direito à aplicação direta e imediata de uma diretiva no período de transposição, mas, sim, que o Estado-membro não pode efetivar atos contrários à diretiva durante esse período. É o que bem esclarece Maria Luísa Duarte: “os Estados-membros não estão obrigados a adotar as medidas de trans-

91 CRUZ VILAÇA, José Luís. A propósito dos efeitos das directivas na ordem jurídica dos Estados-membros. Justica Administrativa, n. 30, p. 3-19, nov./dez. 2001.

92 UNIÃO EUROPÉIA. Tribunal de Justiça. Acórdão TJUE de 21 de Março de 1997, Comissão/Bélgica, 102/79, Rec. 1473, nº 12.

93 UNIÃO EUROPÉIA. Tribunal de Justiça. Acórdão TJUE de 18 de Dezembro de 1997, Inter-Environnement, Proc. C-129/96, Col., p. I-411

94 UNIÃO EUROPÉIA. Tribunal de Justiça. Acórdão TJUE de 18 de Dezembro de 1997, Proc. C-129/96, Col. 1997, p. I-7411, nº 45.

95 UNIÃO EUROPÉIA. Tribunal de Justiça. Acórdão TJUE de 18 de Dezembro de 1997, Proc. C-129/96, Col. 1997, p. I-7411, nº 45. posição, mas estão impedidos de usar esse período de tempo para, por exemplo, aprovar legislação em sentido contrário ao programa de harmonização que resulta do texto da diretiva". Assim, caso o Estado-membro não observe essa obrigação de não fazer, Maria Luísa Duarte admite que os particulares exijam dos tribunais nacionais a não-aplicação da norma ou, em pedido alternativo, que o Estado seja condenado a indenizar por violação do princípio da confiança legítima.

Nesse ponto, a jurisprudência do Tribunal de Justiça reforça a doutrina que defende que a obrigação de interpretação conforme existe desde a data de entrada em vigor da diretiva e não apenas a partir da data de expiração do prazo de transposição ${ }^{96}$.

Como elucida José Luis da Cruz Vilaça, o Tribunal de Justiça ${ }^{97}$, inclusive, já admitiu que uma diretiva que não havia sequer entrado em vigor pudesse ser tida em consideração para a definição dos critérios a serem aplicados pelas autoridades competentes na interpretação do direito nacional. Isso ocorre quando uma diretiva dispõe sobre princípios gerais que já fazem parte, na matéria em causa, do direito dos Estados-membros ${ }^{98}$. Essa possibilidade de aplicação direta de uma diretiva antes de findo o período de transposição, será objeto de análise no decorrer deste trabalho.

\section{Conflito entre o direito comunitário e o DIREITO NACIONAL}

As relações entre o direito da União Europeia e o direito nacional caracterizam-se também pelo fato de ambas, por vezes, regularem a mesma situação fática. Esse

96 CRUZ VILAÇA, José Luís. A propósito dos efeitos das directivas na ordem jurídica dos Estados-membros. Justica Administrativa, n. 30, p. 3-19, nov./dez. 2001. No mesmo sentido, Cf. VAN GERVEN, Walter. The horizontal effect of directive provisions revisited: the reality of Catchwords. University of Hull, Institute of European Public Law, 1993.

97 UNIÃO EUROPÉIA. Tribunal de Justiça. Acórdão TJUE de 14 de Setembro de 2000, Trevor and Penny Fisher, Proc. C-369/98, Col. 2000 , p. I-6751, principalmente $\mathrm{n}^{\circ} 33-34$. Estava em causa, neste acórdão, a aplicação da diretiva n ${ }^{\circ}$ 95/46/CE do Parlamento Europeu e do Conselho, de 24/10/1995, relativa a proteção das pessoas singulares no que diz respeito ao tratamento de dados pessoais e à livre circulação desses dados. CRUZ VILAÇA, José Luís. A propósito dos efeitos das directivas na ordem jurídica dos Estadosmembros. Justiça Administrativa, n. 30, p. 3-19, nov./dez. 2001.

98 CRUZ VILACA, José Luís. A propósito dos efeitos das directivas na ordem jurídica dos Estados-membros. Justiça Administrativa, n. 30, p. 3-19, nov./dez. 2001. 
espaço internormativo, "caracterizado pelo dualismo de ordens jurídicas distintas a operar no mesmo território e sobre os mesmos sujeitos, em diferentes domínios"99, possibilita a existência de conflitos normativos.

O espaço internormativo é uma das principais características da nova ordem jurídica da União Europeia. O principal problema de uma pluralidade normativa é resolver os conflitos oriundos das antinomias. A solução dos conflitos entre o direito interno e a União Europeia foi construída por meio de dois institutos: o efeito direto e o primado do direito comunitário sobre o direito nacional que lhe é contrário.

\subsection{O princípio do primado}

Uma vez que uma das características da União Europeia é a existência do espaço internormativo, surge a seguinte questão: como lidar com as antinomias, ou seja, como resolver os conflitos normativos entre o direito da União Europeia e o direito nacional?

Embora não exista previsão expressa em nenhum dos Tratados instituidores da União Europeia sobre como resolver os conflitos normativos dentro dos espaços internormativos, o Tribunal de Justiça reconheceu o primado como princípio implícito e afirmou o seu caráter essencial, enquanto decorrência dos seguintes institutos: 1) do efeito direto e 2) dos pressupostos dos princípios da interpretação e da interpretação conforme do direito da União Europeia.

Com efeito, o conflito entre o direito nacional e o direito da União Europeia só pode ser resolvido na medida em que seja dado ao direito da União Europeia o primado sobre o direito nacional. Caso contrário, o direito da União Europeia já teria se dissipado perante o direito nacional, uma vez que as disposições da União Europeia poderiam ser anuladas por qualquer lei nacional e, assim, estaria excluída a sua aplicação uniforme nos vários Estados-membros ${ }^{100}$.

No bojo do Acórdão Costa/Enel o Tribunal de Justiça formulou duas considerações fundamentais em face

99 DUARTE, Maria Luísa. O tempo e a transposição de diretivas no direito da União Europeia. In: ESTUDOS em homenagem a Miguel Galvão Teles. Coimbra: Almedina, 2012. v. 1. p. 423-439.

100 BORCHARDT, Klaus-Dieter. $O A B C$ do direito comunitário. 1986. Disponível em <http://www.dhnet.org.br/direitos/sip/ euro/ue_abc_dir_comunitario.pdf $>$. Acesso em: 05 jun. 2013. p. 100. das relações entre o direito comunitário e direito nacional, são elas:

1) Os Estados-membros transferiram de forma definitiva para uma Comunidade por eles criadas certos direitos soberanos. Os referidos Estados não podem voltar atrás em relação a essa transferência, através de medidas unilaterais incompatíveis com o conceito de "comunidade".

2) O tratado estabelece como princípio fundamental que um Estado-membro não pode pôr em causa a particularidade que tem o direito comunitário de se impor uniforme e completamente no conjunto da comunida ${ }^{101}$.

No âmbito do processo Simmenthal ${ }^{102}$, o Tribunal de Justiça analisou as consequências da aplicação direta de norma de direito da União Europeia incompatível com uma norma interna. O Tribunal entendeu que as normas de direito da União produzem todos os seus efeitos "de modo uniforme em todos os Estados-membros, a partir da sua entrada em vigor" ${ }^{\prime 103}$. O mencionado Acórdão consignou ainda que em caso de antinomia entre as normas da União e as de direito interno prevalecem as primeiras.

O direito da União Europeia tem o primado sobre toda e qualquer norma jurídica de direito nacional a ele contrário. Prevalece não só sobre a legislação anterior, mas também sobre todos os atos legislativos ulteriores. A consequência jurídica do princípio do primado é que em caso de antinomia predomina a disposição da União Europeia em face do direito interno, além de não poder ser introduzida, futuramente, nenhuma norma de direito interno que seja incompatível com a legislação da União Europeia ${ }^{104}$.

Ana Maria Guerra Martins ${ }^{105}$ sintetiza as obrigações decorrentes do princípio do primado do direito da União Europeia e os seus efeitos no ordenamento jurídico de um Estado-membro:

1. a não aplicação do Direito nacional incompatível, imposta a todas as autoridades nacionais;

101 UNIÃO EUROPÉIA. Tribunal de Justiça. Acórdão TJUE de 15 de Julho de 1964, Costa c. Enel, Proc. 06/64, Col. 1964, p. 549.

102 UNIÃO EUROPÉIA. Tribunal de Justiça. Acórdão TJUE de 09 de Março de 1978, Simmenthal, Proc. 106/77, Col. 1978, p. 629.

103 UNIÃO EUROPÉIA. Tribunal de Justiça. Acórdão TJUE de 09 de Março de 1978, Simmenthal, Proc. 106/77, Col. 1978, p. 629.

104 BORCHARDT, Klaus-Dieter. $O A B C$ do direito comunitário. 1986. Disponível em <http://www.dhnet.org.br/direitos/sip/ euro/ue_abc_dir_comunitario.pdf>. Acesso em: 05 jun. 2013. p. 101.

105 MARTINS, Ana Maria Guerra. Op. cit., p. 431 e ss. 
2. a interpretação do direito nacional conforme o Direito da União Europeia;

3. a supressão de qualquer acto de Direito nacional incompatível com as disposições do Direito da União Europeia;

4. o controle jurisdicional efectivo do Direito da União Europeia;

5. a obrigação imposta aos Estados-membros de fazer os seus nacionais respeitar o Direito da União Europeia, em especial à luz do princípio da leal cooperação.

O primado completa o efeito direto, pois, nada adiantaria que uma norma da União Europeia tivesse efeito direto e não pudesse contrariar o ordenamento jurídico nacional. Da mesma forma, o primado é completado pelo efeito direto, pois, também seria inócuo que as normas da União Europeia prevalecessem sobre o direito interno se, porém, fosse necessário que o Estado-membro efetuasse algum ato interno para que as normas da União pudessem ser invocadas pelos sujeitos nacionais titulares dos direitos garantidos pela União Europeia, uma vez que a inércia do Estado acabaria com a efetividade do direito da União Europeia.

\subsection{O efeito direto}

Muitas vezes o efeito direto é conceituado como sinônimo de aplicabilidade imediata ${ }^{106}$. Com isso surge a questão: justifica-se ou não distinguir entre efeito direto e aplicabilidade imediata?

José Luis da Cruz Vilaça ${ }^{107}$ identifica que grande parte da responsabilidade por esta imprecisão terminológica existente é oriunda de noções de direito internacional público, desenvolvidas, em especial, pela jurisprudência americana e pelo Tribunal de Justiça, que confrontadas com a crescente autonomização do direito comunitário, foram revelando-se menos apropriadas para captar a complexidade inerente às relações entre União Euro-

106 Ao enunciar o programa decisório do Acórdão, o Supremo Tribunal Administrativo de Portugal parece aceitar a equivalência dentre os dois conceitos. Com efeito, ele consigna que "interessará, assim, de forma, sucinta, apreciar a questão da aplicabilidade directa ou do efeito directo na ordem jurídica interna das normas ou actos comunitários". STA - JOCE L 185, de 16/08/1971, p. 5. Na doutrina, Cf. CAMPOS, João da Mota. Manual de direito comunitário. 3. ed. Lisboa: Fundação Caloute Gulbenkian, 2002. p. 361 e ss.

107 CRUZ VILAÇA, José Luís. A propósito dos efeitos das directivas na ordem jurídica dos Estados-membros. Justiça Administrativa, n. 30, p. 3-19, nov./dez. 2001. peia e direito nacional dos Estados-membros ${ }^{108}$.

Porém, a aplicabilidade imediata é um dos principais critérios distintivos entre os regulamentos e as diretivas, por essa razão, a diferenciação entre os dois institutos (aplicabilidade imediata e efeito direto) ainda é útil.

A aplicabilidade imediata é um efeito das normas da União Europeia que entram em vigor nos ordenamentos jurídicos dos Estados-membros, independentemente de qualquer ato de transposição. Sobre o tema, o Tribunal de Justiça assim se manifestou: "a aplicabilidade directa de um regulamento exige a sua entrada em vigor e a sua aplicação em favor ou a cargo dos sujeitos de direito se realizem sem qualquer medida de recepção no direito nacional” ${ }^{109}$.

Enquanto o efeito direto se caracteriza pelo fato de tornar possível a invocação de normas expedidas pela União Europeia, que contenham direitos e/ou obrigações para particulares perante os tribunais nacionais. Efeito direto ${ }^{110}$ significa, assim, que o ordenamento jurídico da União Europeia cria obrigações e confere direitos, não só para as instituições da União Europeia e os Estados-membros, mas também para os cidadãos da União Europeia.

A aplicabilidade imediata é um princípio por força do qual o direito da União Europeia aplica-se na ordem interna sem que se torne necessário assegurar o seu reconhecimento ou a sua transposição para o direito nacional. O direito da União Europeia é, assim, integrado de pleno direito no ordenamento nacional. Enquanto o efeito direto permite aos particulares invocar normas da União, junto aos tribunais nacionais, sem depender de textos nacionais que se destinem a concretizá-las ${ }^{111}$. Este princípio reforça a eficácia do direito da União e a salvaguarda dos direitos dos particulares, permitindo que uma norma da União Europeia vija, independente-

108 Cf. MÉGRET, Jacques. Le droit de la Communauté économique européenne: pt. 1-2. La cour de justice, les actes des institutions. Bruxelles: Universitaires de Bruxelles, 1983. p. 543.

109 UNIÃO EUROPÉIA. Tribunal de Justiça. Acórdão TJUE de 10 de Outubro 1973, Variola, 34/73, Col. 1973, p. 365.

110 Cf. UNIÃo EUROPÉIA. Tribunal de Justiça. Acórdão TJUE de 10 de Outubro 1973, Variola, 34/73, Col. 1973, p. 365; Leonesio, de 17 de maio de 1992, Proc. 93/71, Rec. 1992, p. 287, no 22 e 23; Politi, Proc. 43/71, de 14 de Dezembro de 1971,Col. 1971, p. 419.

111 Cf. SOUSA, Marcelo Rebelo de. A transposição das directivas comunitárias para a ordem jurídica nacional. INA, Oeiras, v. 4/5, p. 69-94, abr./dez. 1992 e WINTER, Jan A. Direct applicability and direct effect: Two distinct and different concepts in Community law. Common Market Law Review, v. 9, n. s 425, 1972. 
mente da existência de textos de origem nacional. Cláudia Lyra Nascimento sintetiza a distinção:

Por eficácia direta entende-se a possibilidade de serem essas normas invocadas pelos particulares, quanto aos direitos e obrigações judiciárias, quando houver sua violação; e, por aplicabilidade imediata, a efetiva aplicação da norma, logo após sua publicação, sem necessidade de processo de reconhecimento ou incorporação no ordenamento jurídico nacional ${ }^{112}$.

Desta feita, o que se observa é que a aplicabilidade direta tem um caráter mais formal, de dispensa da adoção de atos procedimentais, ao passo que o efeito direto apresenta caráter nitidamente material, criando direitos e obrigações aos destinatários.

Embora o efeito direto não tenha sido expressamente consagrados nos Tratados da União Europeia, a Jurisprudência do Tribunal de Justiça os reconheceu ${ }^{113}$, apesar da resistência inicial de determinados Estados-membros ${ }^{114}$.

O leading case ocorreu no caso Van Gend en Loos ${ }^{115}$. Refere-se a uma empresa holandesa que ajuizou ação contra a administração fiscal de seu país, pelo fato de a Administração pretender cobrar um montante maior de tributo relativo à importação de um produto químico da Alemanha ${ }^{116}$.

A questão apreciada pelo Tribunal de Justiça foi se o art. $12^{\circ}$ do Tratado da $\mathrm{CEE}^{117}$, que proíbe expressamente a introdução de novos direitos aduaneiros ou o aumento dos existentes, produz efeito direto no território dos Estados-Membros ${ }^{118}$.

112 NASCIMENTO, Cláudia Lyra. O dilema da incorporação das normas do Mercosul no ordenamento jurídico brasileiro. Revista de Informação Legislativa, Brasília, ano 43, n. 172, out./dez. 2006. Disponível em: <http://www2.senado.gov.br/bdsf/item/id/93272>. Acesso em: 10 abr. 2013.

113 Sobre as normas da União Europeia terem o efeito direto como regra, Cf. PESCATORE, Pierre. The Doctrine of 'Direct Effect': An Infant Disease of Community Law. Euro-pean Law Review, n. 8 , p. $155,1983$.

114 BORCHARDT, Klaus-Dieter. $O A B C$ do direito comunitário. 1986. Disponível em <http://www.dhnet.org.br/direitos/sip/ euro/ue_abc_dir_comunitario.pdf $>$. Acesso em: 05 jun. 2013. p. 97.

115 UNIÃo EUROPÉIA. Tribunal de Justiça. Acórdão TJUE de 5 de Fevereiro de 1963, Van Gend en Loos, Proc 26/62, Col. 1963, p. 00205.

116 BORCHARDT, Klaus-Dieter. $O A B C$ do direito comunitário. 1986. Disponível em <http://www.dhnet.org.br/direitos/sip/euro/ ue_abc_dir_comunitario.pdf>. Acesso em: 05 jun. 2013.p. 97. 117 Antigo art. $25^{\circ}$ do Tratado CE e atual art. 30 do TFUE.

118 BORCHARDT, Klaus-Dieter. $O A B C$ do direito comunitário.
Em suma, o Tribunal holandês (Tarief Comissie) suscitou ao Tribunal de Justiça se uma norma do Tratado de Roma, claramente dirigida aos Estados-membros, é susceptível de garantir aos particulares o direito de respeito pelos Estados da cláusula "stand Still"119, cláusula essa que foi estabelecida para o período transitório até a abolição dos direitos aduaneiros entre os Estados-membros.

O Tribunal de Justiça pronunciou-se em sentido contrário ao disposto em pareceres de vários governos e do seu advogado-geral ${ }^{120}$ e reconheceu o efeito direto, tendo em conta a natureza e os objetivos da União Europeia, conforme se verifica no seguinte trecho ${ }^{121}$. Assim, o Tribunal garantiu que a empresa Van Gend \& Loos poderia basear-se no art. $12^{\circ}$ do Tratado CEE. Logo, o Tribunal holandês deveria considerar ilícito o aumento do tributo de importação, porque contrário às disposições do Tratado.

Nesse mesmo Acórdão, o Tribunal de Justiça fixou requisitos mínimos para uma norma produzir efeito direto, a saber: 1) que a norma fosse clara e sem elevado grau de ambiguidade, 2) que a norma fosse incondicional, 3) que a respectiva operacionalidade não dependesse de normas posteriores comunitárias ou nacionais, ou seja, que vinculasse obrigações negativas.

Porém, alguns dos requisitos inicialmente fixados foram alterados com a evolução jurisprudencial sobre o tema. O requisito da clareza foi derrogado pelo argumento de que a falta deste requisito caracteriza normas de complexo normativo de qualquer ordem jurídica, permitindo interpretações diversas. No direito comunitário, compete ao Tribunal de Justiça a interpretação de normas complexas, logo, o Tribunal, ao exigir a clareza da norma, para possibilitar que a mesma tivesse efeito direto, na verdade estava omitindo-se, logo, denegando a justiça. Pela atividade interpretativa do Tribunal chega-se à clareza da norma, pois resulta apreciação clara

1986. Disponível em <http://www.dhnet.org.br/direitos/sip/ euro/ue_abc_dir_comunitario.pdf>. Acesso em: 05 jun. 2013.p. 97 119 Em sede tributária, essa cláusula obriga que seja aplicada as alíquotas dos impostos preferenciais, quando estas, calculadas nos termos da legislação da União Europeia proporcionarem uma redução mais elevada no total a pagar do tributo.

120 BORCHARDT, Klaus-Dieter. $O A B C$ do direito comunitário. 1986. Disponível em <http://www.dhnet.org.br/direitos/sip/ euro/ue_abc_dir_comunitario.pdf>. Acesso em: 05 jun. 2013.p. 97 121 UNIÃO EUROPÉIA. Tribunal de Justiça. Acórdão TJUE de 5 de Fevereiro de 1963, Van Gend en Loos, Proc 26/62, Col. 1963, p. 00205. 
quanto ao sentido, ao alcance e à extensão da norma ${ }^{122}$.

O terceiro requisito também foi relativizado no julgamento do caso Defrenne v. Sabena ${ }^{123}$, em que o Tribunal pronunciou-se sobre o efeito direto do art. 119 do Tratado $\mathrm{CEE}^{124}$, cuja redação determinava uma obrigação positiva aos Estados-membros a ser cumprida dentro de um determinado lapso temporal. O Tribunal de Justiça entendeu que o efeito direto não deixa de ser qualidade da norma, apesar das exigências de uma ação nacional posterior. Significa apenas que o efeito direto é diferido no tempo sempre que a norma estabelecer um prazo limite ${ }^{125}$.

A jurisprudência firmada pelo Tribunal de Justiça sobre o tema, que perdura até o momento, firmou-se na determinação de dois requisitos da norma para condição de efeito direto: a precisão e a incondicionalidade.

O Tribunal de Justiça, posteriormente, estendeu a interpretação do efeito direto construída em face do art. $12^{\circ}$ do Tratado da CEE para outras disposições do Tratado, por exemplo, o art. $39^{\circ}$ (livre circulação) ${ }^{126}$, o art. $43^{\circ}$ (liberdade de estabelecimento) ${ }^{127}$ e o art. $49^{\circ}$ (livre prestação de serviço) $)^{128}$ do Tratado da CEE $^{129}$.

\subsubsection{O efeito direto das disposições do direito derivado}

O processo legislativo ordinário consiste na adoção de um regulamento, de uma diretiva ou de uma decisão. Esses institutos da União Europeia contêm particulari-

122 COELHO, Teresa Leal. A jurisprudência do Tribunal de Justiça das comunidades relativa ao efeito directo da directiva comunitária. Disponível em: <http://www.estig.ipbeja.pt/ ac_direito/caracterizacao_oj_ comunitaria.pdf $>$. Acesso em: 04 maio 2013.

123 UNIÃO EUROPÉIA. Tribunal de Justiça. Acórdão TJUE de 08 de Abril de 1976, Defrenne v. Sabena, Proc. 43/75, Col. 1976, p. 193.

124 Atual art. 157 do TFUE.

125 COELHO, Teresa Leal. A jurisprudência do Tribunal de Justiça das comunidades relativa ao efeito directo da directiva comunitária. Disponível em: <http://www.estig.ipbeja.pt/ ac_direito/caracterizacao_oj_ comunitaria.pdf $>$. Acesso em: 04 maio 2013.

126 UNIÃO EUROPÉIA. Tribunal de Justiça. Acórdão TJUE de 04 de Dezembro de 1974, Van Duyn, Proc. 41/74, Col. 1974, p. 567.

127 UNIÃO EUROPÉIA. Tribunal de Justiça. Acórdão TJUE de 21 de Junho de 1974, Reyners, Proc. C-2/74, Col. 1974, p. 325.

128 UNIÃo EUROPÉIA. Tribunal de Justiça. Acórdão TJUE de 03 de Dezembro de 1974, Van binsbergen, Proc. C- 33/74. Col. 1974, p. 543.

129 BORCHARDT, Klaus-Dieter. $O A B C$ do direito comunitário. 1986. Disponível em <http://www.dhnet.org.br/direitos/sip/ euro/ue_abc_dir_comunitario.pdf>. Acesso em: 05 jun. 2013. dades quanto ao efeito direto das normas por eles concretizadas.

Com efeito, o art. $288^{\circ}$ do TFUE dispõe que os regulamentos são "diretamente aplicáveis em todos os Estados-membros”. O Tribunal de Justiça reconheceu, ainda, para os regulamentos, o efeito direto completo no caso Politi ${ }^{130}$.

É fácil ver que é o próprio Tratado de Roma que atribui efeito direto e aplicabilidade imediata ao regulamento da União. Porém, nada impede que o próprio regulamento estabeleça condições para a sua aplicação. Nesse caso, explica João Mota de Campos que a aplicabilidade direta do regulamento não deve ser confundida com a sua aplicabilidade imediata, uma vez que é o próprio regulamento que subordina a sua aplicação à intervenção de medidas posteriores de execução a serem adotadas pelas instituições da União Europeia ou pelos Estados-membros. Nesses casos, somente após a efetivação de tais medidas é que as disposições dos regulamentos poderão ser aplicadas pelos tribunais nacionais $^{131}$.

As decisões dirigidas a particulares, indivíduos ou empresas, resultam direitos ou obrigações a favor ou a cargo de seus destinatários, o que implica sua aplicabilidade direta na ordem dos Estados-membros. $\mathrm{O}$ ato da União Europeia constitui título executivo contra o destinatário, nos casos em que ele determina uma obrigação pecuniária ${ }^{132}$.

Porém, mesmo as decisões dirigidas a pessoas privadas individualmente identificadas são capazes de gerar, por si próprias, direitos a favor de terceiros. O exemplo citado por João Mota de Campos para elucidar a questão refere-se a uma decisão da Comissão que declare a ilegalidade de um cartel ou reconhece a existência de uma situação de abuso de posição dominante. Nesses casos, as vítimas eventuais dessas situações violadoras dos arts. $101^{\circ}$ e $102^{\circ}$ do TFUE estão habilitadas a requerer uma indenização diretamente ao juiz nacional, com fulcro na mencionada decisão ${ }^{133}$.

130 UNIÃO EUROPÉIA. Tribunal de Justiça. Acórdão TJUE de 14 de Dezembro de 1971, Politi, Proc. 43/71, Col. 1971, p. 419.

131 CAMPOS, João Luiz Mota. Manual de direito europeu: o sistema institucional, a ordem jurídica e ordenamento económico da União Europeia. 6. ed. Coimbra: Coimbra, 2010. p. 374.

132 CAMPOS, João Luiz Mota. Manual de direito europeu: o sistema institucional, a ordem jurídica e ordenamento económico da União Europeia. 6. ed. Coimbra: Coimbra, 2010. p. 375.

133 CAMPOS, João Luiz Mota. Manual de direito europeu: o sistema 
O Tribunal de Justiça também já se manifestou sobre o efeito direto das decisões dirigidas aos Estados-membros e, segundo a sua jurisprudência iniciada no caso Franz Grad ${ }^{134}$, não é pelo fato do art. $288^{\circ}$ do TFUE determinar que os regulamentos tenham efeito direto que todos os demais instrumentos do direito derivado não o têm. Não resulta desse dispositivo, pelo argumento "a contrário", que os demais atos descritos no mesmo artigo não possam em nenhum caso produzir efeitos diretos. Assim, o Tribunal de Justiça ao efetuar uma interpretação teleológica da norma entendeu que se a decisão impuser ao Estado-membro uma obrigação incondicional e suficientemente precisa para poder ser aplicada por si própria, essa decisão é susceptível de produzir efeito direto nas relações entre Estado-membro e particular ${ }^{135}$. Porém, no âmbito das decisões individuais em que o Estado-membro é o único destinatário, o Tribunal de Justiça aceitou unicamente o efeito direto vertical ${ }^{136}$.

O efeito direto dos regulamentos distingue-se do efeito direto das diretivas porque essas últimas, segundo o disposto no art. $288^{\circ}$ do TFUE, apenas vinculam o Estado-membro destinatário quanto ao resultado a alcançar, deixando, no entanto, às instâncias nacionais a competência quanto à forma e aos meios. Porém, essa liberdade não é absoluta, ela é restringida pelos princípios da lealdade, da proteção e da vedação do abuso de direito. Assim, a transposição tem que ser feita de forma que garanta a eficácia da norma dentro do Estado-membro. Caso a transposição não seja realizada ou seja feita de forma insuficiente ou errada, o Estado-membro estará em mora e terá agido de forma ilícita. Com intuito de não permitir que o Estado infrator seja beneficiado pela própria torpeza, o Tribunal de Justiça evoluiu a sua jurisprudência para admitir, desde que cumpridos alguns requisitos, o efeito direto da diretiva. Porém, não é a diretiva que vige diretamente, mas são as normas que estão contidas na diretiva que passam a viger. Assim sendo, percebe-se que a eficácia vertical de

institucional, a ordem jurídica e ordenamento económico da União Europeia. 6. ed. Coimbra: Coimbra, 2010. p. 375.

134 UNIÃO EUROPÉIA. Tribunal de Justiça. Acórdão TJUE de 06 de Outubro de 1970, Franz Grad, Proc. 9/70, Rec. 1970, p. 825.

135 CAMPOS, João Luiz Mota. Manual de direito europeu: o sistema institucional, a ordem jurídica e ordenamento económico da União Europeia. 6. ed. Coimbra: Coimbra, 2010.p. 376.

136 UNIÃO EUROPÉIA. Tribunal de Justiça. Acórdão TJUE de 10 de Novembro de 1992, Hansa Fleisch, Proc. C-156/91, Col. 1992, p. I-05567. uma Diretiva decorre da infração cometida pelo Estado.

Diferentemente é a fundamentação para que uma diretiva possa viger horizontalmente, ou seja, entre particulares, uma vez que nesse caso não há ato ilícito perpetrado pela outra parte. Nesse caso, para aqueles que defendem essa possibilidade, o fundamento seria o intuito de garantir plenamente que os titulares de um direito, concedido por normas da União Europeia, venham a exerce-los. A questão será melhor aprofundada no próximo tópico, mas, por enquanto, já é possível apontar algumas diferenças entre o efeito direto de uma diretiva e o de um regulamento:

1) $\mathrm{O}$ efeito direto da diretiva só ocorre após transcorrido o prazo de transposição da diretiva, caso o Estado tenha permanecido inerte; e nos casos em que há não cumprimento defeituoso da diretiva pelo Estado destinatário. Enquanto o regulamento produz efeito direto a partir do seu respectivo início de vigência (art. $297^{\circ}$ do TFUE).

2) Nas diretivas cabem aos Estados-membros a escolha da forma e dos meios que considerem adequados à prossecução dos objetivos por ela fixados, enquanto nos regulamentos, o Estadomembro não está autorizado a intermediar a produção do efeito direto.

3) Nos regulamentos, o efeito direto é inerente à sua natureza e função, já nas diretivas o efeito direto é excepcional.

A jurisprudência do Tribunal de Justiça firmou-se numa concepção restritiva quanto ao efeito direto da diretiva, seus efeitos são mais restritos do que os regulamentos.

Em face dessa concepção mais restritiva, o Tribunal consagrou um conjunto de outros princípios para colmatar essa distorção, fornecendo aos particulares outros instrumentos e/ou meios de ressarcimento pela não efetivação direta dos direitos consagrados nas diretivas, tais como: o princípio da interpretação conforme e o instituto da responsabilidade patrimonial do Estado pelos danos provocados em face da violação do direito da União Europeia.

\subsubsection{Evolução jurisprudencial do efeito direto das diretivas}

Embora não seja objeto do presente trabalho verificar se a jurisprudência é ou não uma fonte secundária do direito da União Europeia, o fato é que ela vem desempenhando papel fundamental na integração da União Europeia em prol de uma unidade política. 
João Mota de Campos esclarece, a esse respeito, que o Tribunal de Justiça tem superado o silêncio e as insuficiências dos Tratados por meio de acórdãos sucessivos e imposto o princípio da autonomia do direito da União Europeia, o princípio da aplicabilidade direta das normas comunitárias e o princípio da sua primazia absoluta sobre o direito interno, além de ter, em certos casos, "criado" o direito e orientado seu desenvolvimento por meio da obediência aos princípios gerais do direito ${ }^{137}$.

Realmente não existe um rol escrito de fontes do direito da União Europeia. A jurisprudência, assim, não está inserida em nenhuma declaração expressa. Porém, fato é que as decisões do Tribunal de Justiça moldaram os princípios e as regras de direito da União Europeia, inclusive dotando-os de normatividade, mesmo quando não expressamente prevista. O Tribunal de Justiça caracteriza-se por ser um tribunal ativista, que tem, nas palavras de Pierre Pescatore, um papel muito maior que o de mero aplicador das normas: “os juízes tinham seu próprio entendimento sobre a Europa, e este entendimento foi decisivo, e não os argumentos baseados na tecnicidade jurídica da matéria." ${ }^{138}$ Essa ideia de integração política da Europa é que impulsiona o Tribunal, sendo que as questões relacionadas com as ferramentas jurídicas não são óbices para que o Tribunal crie a sua jurisprudência em direção à integração almejada, logo, nesse cenário, a jurisprudência passa a ter uma posição de destaque. Sobre o tema, esclarece Maria Luísa Duarte:

\begin{abstract}
A permanente e fecunda representação de "uma certa ideia da Europa" pelo Tribunal de Justiça levou-o a reservar a mais empenhada prioridade interpretativa ao espírito dos Tratados em detrimento da letra dos Tratados. Foi essa visão reconstrutiva dos textos normativos - que alguns verberam como manifestações de "activismo judicial" - que tornou possível ao Tribunal de Justiça, sempre inspirado no chamado "espírito do sistema", extrair do silêncio dos Tratados princípios fundamentais como o do primado e o do efeito directo, garantir a protecção comunitária dos Direitos Fundamentais, impor aos Estados-membros o dever de indemnizar os prejuízos resultantes de violação do Direito Comunitário, adaptar a extensão das competências das Comunidades ao escopo integracionista da actuação das instituições comunitárias ${ }^{139}$.
\end{abstract}

137 CAMPOS, João da Mota. Direito Comunitário. Lisboa: Fundação Calouste Gulbenkian, 1994. v. 2. p. 181

138 PESCATORE, Pierre. The doctrine of 'direct effect': an infant disease of community law. Euro-pean Law Review, n. 8, p. 157, 1983.

139 DUARTE, Maria Luísa. União Europeia: estática e dinâmica da ordem jurídica Eurocomunitária. Coimbra: Almedina, 2011. p. 242.
Por essa razão, percebe-se que para compreender o real efeito das diretivas é fundamental analisar a jurisprudência do Tribunal de Justiça sobre o tema, uma vez que ela há muito tempo superou a letra fria da lei.

As disposições de uma diretiva não vigem, como regra, diretamente no ordenamento jurídico nacional. No caso de Portugal, especificamente, elas são recebidas nos termos do art. $8^{\circ}$ da Constituição da República Portuguesa. Porém, os Estados-membros estão obrigados a efetuar a transposição para o seu ordenamento nacional. Diante disso, "não se pode dizer que as diretivas criam direitos e obrigações directos para os cidadãos da UE: os cidadãos da UE só ficam sujeitos a direitos e obrigações quando as autoridades competentes dos Estados-membros executam a directiva" ${ }^{140}$. Apenas com a transposição da diretiva é que o cidadão poderá exercer plenamente os direitos nela contidos.

Contudo, diante da possibilidade de os Estados-membros, arbitrariamente, não procederem à transposição devida, o que implicaria perda de eficácia dos direitos e objetivos da União Europeia, o Tribunal de Justiça possibilitou que as diretivas produzam alguns efeitos, a fim de proteger os cidadãos da inércia estatal e garantir que os titulares dos direitos consagrados nas diretivas não ficassem prejudicados pela mora do Estado-membro, ou mesmo pela insuficiente ou indevida transposição de uma diretiva para o ordenamento nacional.

Assim, justamente com o intuito de evitar o perecimento de direitos pelos cidadãos nacionais em virtude das diretivas não transpostas em tempo hábil e, ainda, a fim de evitar que a conduta omissiva estatal permaneça sem sanção, o Tribunal de Justiça tem reiteradamente afirmado que os cidadãos podem invocar diretamente uma diretiva, desde que preenchidas algumas condições ${ }^{141}$.

A evolução dessa construção iniciou-se a partir do acórdão Franz $\mathrm{Grad}^{142}$, em que o Governo Federal da Alemanha sustentava que apenas os regulamentos tinham efeito direto, enquanto as diretivas e os pareceres,

140 CUNHA, Ricardo Sousa da. Introdução diacrónica e incrónica ao direito da União Europeia. Disponível em: < https://woc.ipca.pt/esg/ getFile.do?tipo=2\&id=7633>. Acesso em: 03 ago. 2013.

141 CUNHA, Ricardo Sousa da. Introdução diacrónica e incrónica ao direito da união europeia. Disponível em: <https://woc.ipca.pt/esg/ getFile.do?tipo=2\&id=7633>. Acesso em: 03 ago. 2013.

142 UNIÃO EUROPÉIA. Tribunal de Justiça. Acórdão TJUE de 06 de Outubro de 1970, Franz Grad, Proc. 9/70, Rec. 1970, p. 511. 
com fulcro no Tratado de Roma, teriam sido excluídos do efeito acima mencionado. Porém, o Tribunal de Justiça entendeu que embora a disposição do art. $288^{\circ}$ do TFUE afirme que os regulamentos são diretamente aplicáveis e, consequentemente, "suscetíveis de produzir efeitos diretos, isto não implica que outras categorias de actos referidos por aquele artigo não possam produzir efeitos análogos".

O efeito direto das diretivas foi reforçado no Acórdão $S_{a c e}{ }^{143}$, em que o Tribunal de Justiça, referindo-se à Diretiva 68/31 da Comissão, manifestou-se no sentido de que uma diretiva produz "consequências jurídicas de que se podem prevalecer tanto os outros Estados-membros, eles próprios interessados no cumprimento, como os particulares, quando pela sua própria natureza a disposição que estabelece essa obrigação seja diretamente aplicável”. Em suma, a interpretação do Tribunal de Justiça supera em muito a literalidade do art. $288^{\circ}$ do Tratado sobre o Funcionamento da União Europeia (TFUE).

No entanto, essa aplicação direta ascendente acabou por firmar-se no Tribunal no acórdão Van Duyn ${ }^{144}$. Yvonne Van Duyn, cidadã holandesa, decidiu emigrar para Inglaterra, a fim de ocupar um posto de trabalho na Igreja Cientológica. Porém, o serviço de imigração, com fulcro no ato do Secretário de Estado, decretou a sua imediata expulsão para os Países Baixos. O ato de expulsão foi motivado por razões de ordem pública.

Em face da negativa obtida, Yvonne Van Duyn recorreu aos tribunais ingleses, invocando o direito de permanecer em território britânico, com fulcro no regime da livre circulação de trabalhadores, inserido no art. 48 do Tratado da $\mathrm{CEE}^{145}$ (atual art. $45^{\circ}$ do TFUE)

143 UNIÃO EUROPÉIA. Tribunal de Justiça. Acórdão TJUE de 17 de Dezembro de 1970, Sace, Proc. 33/70, Col. 1969/1970, p. 685. 144 UNIÃO EUROPÉIA. Tribunal de Justiça. Acórdão TJUE de 04 de Dezembro de 1974, Van Duyn, Proc. 41/74, Col. 1974, p. 567.

145 Artigo $48^{\circ}$ - 1. A livre circulação dos trabalhadores deve ficar assegurada, na comunidade, o mais tardar no termo do período de transição.

2. A livre circulação dos trabalhadores implica a abolição de toda e qualquer discriminação em razão da nacionalidade, entre os trabalhadores dos Estados-membros, no diz respeito ao emprego, à remuneração e demais condições de trabalho.

3. A livre circulação dos trabalhadores compreende, sem prejuízo das limitações justificadas por razões de ordem pública, segurança pública e saúde pública, o direito de: a) Responder a ofertas de emprego efectivamente feitas;

b) Deslocar-se livremente, para o efeito, no território dos Estadosmembros; c) Residir num dos Estados-membros a fim de nele ex- e, ainda, no $n^{\circ} 1$, do art. $3^{\circ}$ da Diretiva 64/221/CEE ${ }^{146}$ para a coordenação das medidas especiais relativas a estrangeiros em matéria de deslocação e estada justificadas por razão de ordem, segurança e saúde públicas.

Assim, a Câmara dos Lordes, a que subiu o processo em recurso, submeteu ao TJUE, pela primeira vez, a questão prejudicial da interpretação do direito comunitário.

O Tribunal de Justiça pronunciou-se no sentido apontado pelo Advogado-Geral:

1. O art. 48 (atual $45^{\circ}$ do TFUE) do Tratado CEE tem efeito directo nas ordens jurídicas dos Estados-membros e confere aos particulares direitos que os órgãos jurisdicionais nacionais devem salvaguardar.

2. $\mathrm{O}$ art. $3^{\circ}, \mathrm{n}^{\circ} 1$, da Directiva 64/221/CEE do Conselho, de 25 de fevereiro de 1964, para coordenação das medidas especiais relativas a estrangeiros em matéria de deslocação e estada justificadas por razões de ordem pública, segurança pública e saúde pública, confere aos particulares direitos que estes podem invocar em juízo e que os órgãos jurisdicionais nacionais devem salvaguardar.

3. $\mathrm{O}$ art. 48 (atual $45^{\circ}$ do TFUE) do Tratado CEE e o art. $3^{\circ}$ da Directiva 64/221 devem ser interpretados no sentido de que, ao impor restrições justificadas por razões de ordem pública, é legítimo que um Estado-membro tome em consideração, como relevante $\mathrm{O}$ comportamento pessoal do indivíduo em causa, o facto de este pertencer a um grupo ou organização cujas actividades são consideradas pelo Estado-membro como um perigo social, sem todavia serem proibidas e sem que sejam impostas quaisquer restrições aos nacionais desse Estado que desejem exercer uma actividade análoga ao serviço desses mesmos grupos ou organizações.

ercer uma actividade laboral, em conformidade com as disposições legislativas regulamentares e administrativas que regem o emprego dos trabalhadores nacionais; d) Permanecer no território de um Estado-membro depois de nele ter exercido uma actividade laboral, nas condições que serão objectivo de regulamentos de execução a estabelecer pela Comissão.

146 Artigo $3^{\circ}-1$. As medidas de ordem pública ou de segurança pública devem fundamentar-se, exclusivamente, no comportamento pessoal do indivíduo em causa. 
Desta forma, o Tribunal de Justiça declarou o efeito direto das diretivas, desde que as disposições dela determinem direitos aos cidadãos da União de forma suficientemente clara e precisa; a invocação desses direitos não deve estar sujeita a qualquer condição ou obrigação; o legislador nacional não disponha de qualquer margem de apreciação acerca do conteúdo desses direitos; e o prazo de transposição da diretiva para o direito interno já tenha expirado.

Todavia, o caso é paradigmático apenas para o efeito direto em sentido vertical ascendente, ou seja, que um particular oponha a diretiva ao Estado incumpridor, jamais no sentido vertical descendente, que possibilitaria que o Estado aproveitasse da própria torpeza para opor a norma constante na diretiva não cumprida a um particular.

A jurisprudência coincidente com a do Acórdão Van Duyn foi, posteriormente, confirmada em numerosos acórdãos que contribuíram para clarificar a noção de efeito direto não apenas das diretivas, mas de todas as disposições do direito da União Europeia em geral.

O Tribunal de Justiça, contudo, não permitiu aplicação de efeitos diretos horizontais à diretiva, conforme constata-se do caso Marshall v. Southampton West Hampshire Area Health Authority ${ }^{147}$ : "A directiva não pode, por si, impor obrigações a um particular e a norma da directiva não pode ser invocada por um particular contra outro particular”. Essa jurisprudência foi confirmada nos Acórdãos Vaneetveld ${ }^{148}$ e Faccini Dori ${ }^{149}$. Ao assim agir, o Tribunal de Justiça foi de encontro ao pensamento da doutrina qualificada ${ }^{150}$ e dos pareceres emitidos por Advogados-Gerais que defendem justamente o contrário.

Isso porque o efeito direto vertical é visto como uma sanção ao Estado-membro pelo fato dele se manter não cumpridor de uma obrigação de transpor os direitos assegurados em determinada diretiva para o direito interno ou transpor, erroneamente, as disposições de uma diretiva. Contudo, na visão do Tribunal de Justiça, seria um ônus demasiadamente gravoso a recair sobre todos

147 UNIÃO EUROPÉIA. Tribunal de Justiça. Acórdão TJUE de 26 de Fevereiro de 1986, Marshall v. Southampton West Hampshire Area Health Authority, Proc. 152/84, Col. 1986, p. 0073.

148 UNIÃO EUROPÉIA. Tribunal de Justiça. Acórdão TJUE de 3 de Abril de 1994, Vaneetveld, Proc. C-316/93, Col. 1994, pgs. I-763. 149 UNIÃO EUROPÉIA. Tribunal de Justiça. Acórdão TJUE de 14 de Julho de 1994, Faccini Dori, Proc. C-91/92, Col. 1994, p I-3.325. 150 Cf. MANIN, Ph. L'invocabilité des directives: quelques interrogations. Revue Trimestrielle de Droit Européen, 1990. p. 669. os particulares o dever de conhecer, em detalhe, a disposição de uma diretiva e decidir não cumprir as disposições do direito nacional naquilo que ele seja contrário ao disposto na diretiva.

O Tribunal fundamentou-se na interpretação do art. $288^{\circ}$ do TFUE para justificar a restrição de efeitos horizontais, uma vez que a diretiva "apenas admite a invocabilidade perante o tribunal nacional contra o Estado-membro destinatário."

Contudo, posteriormente, o Tribunal de Justiça alargou o entendimento de Estado-membro, com o fito de abarcar também o Estado-administração, o Estado-empregador e todas as pessoas coletivas públicas, incluindo, autarquias locais e os municípios, "assim como os organismos e as entidades que estejam sujeitas à autoridade e ao controle do Estado, ou que disponham de poderes exorbitantes em relação aos que resultam das regras aplicáveis às relações entre particulares, o que engloba as empresas públicas"151.

Esse entendimento foi reforçado no caso Nijmegen ${ }^{152}$. O Tribunal de Justiça expressou a necessidade da interpretação conforme do direito nacional em face das diretivas, dos regulamentos e dos Tratados e ainda aduziu que sempre que "as disposições de uma diretiva se revelem, do ponto de vista do seu conteúdo, incondicionais e suficientemente precisas" os particulares poderão invocá-las contra o Estado, após transcorrido o prazo de transposição e o Estado-membro destinatário tiver mantido-se inerte ou tenha efetuado uma transposição incorreta da diretiva. Afirmou ainda que diretivas não podem, por si próprias, "criar obrigações para os particulares e, deste modo, não podem ser invocadas enquanto tais contra eles, perante um órgão jurisdicional nacional" ${ }^{\prime 153}$.

Desta forma, o acórdão Nijmengen reafirma a proibição relativa ao efeito direto horizontal da diretiva, já decretado pelo acórdão Marshall, bem como determina a obrigação da observância do princípio da interpretação conforme, já enunciado pelo acórdão Von Colson ${ }^{154}$. O Tribunal de Justiça afirma que é dever dos tribunais

151 QUADROS, Fausto de. Direito da União Europeia. Coimbra: Almedina, 2004. p. 436.

152 UNIÃO EUROPÉIA. Tribunal de Justiça. Acórdão TJUE de 08 de Outubro de 1987, Nijmegen, Proc. 80/86, Col. 1987, p. 3969.

153 UNIÃo EUROPÉIA. Tribunal de Justiça. Acórdão TJUE de 08 de Outubro de 1987, Nijmegen, Proc. 80/86, Col. 1987, p. 3969. 154 UNIÃO EUROPÉIA. Tribunal de Justiça. Acórdão TJUE de 10 Abril de 1984, Von Colson, Proc. 14/83, Col. 1984, p. 00515. 
nacionais ao utilizar-se do princípio da interpretação conforme de uma diretiva, alcançar o resultado referido no terceiro parágrafo do art. $189^{155}$ (atual 288º. Porém introduziu alguns limitadores para essa obrigação, são eles: os princípios gerais do direito comunitário, o princípio da segurança jurídica e o da não-retroatividade, impedindo, desta forma, que uma diretiva, por si só, gere obrigações aos particulares.

O entendimento esposado nos casos Marshall e Ninjmengen, sobre a vedação de efeito direto horizontal, foi reforçado no caso Faccini Dori v. Recreb ${ }^{156}$, conforme excerto abaixo:

A possibilidade de invocação de direitos contra entidades estatais assenta no caráter obrigatório que o art. 189, lhes reconhece, e que só existe para o Estado-membro destinatário e visa evitar que um Estado possa tirar proveito da sua inobservância do direito comunitário. Com efeito, seria inaceitável que o Estado, a que o legislador comunitário impôs a adopção de determinadas regras destinadas a reger as suas relações ou as das entidades estatais com os particulares, e a conferir a estes o benefício de certos direitos, possa invocar a inexecução dos seus deveres para privar os particulares do benefício desses direitos. Alargar este princípio ao domínio das relações entre os particulares equivaleria a reconhecer à comunidade o poder de criar, com efeito directo, deveres na esfera jurídica dos particulares quando ela só tem essa competência nas áreas em que lhe é atribuido o poder de adoptar regulamentos. Daqui resulta que, na falta de medidas de transposição nos prazos prescritos, um particular não pode basear-se numa directiva para pretender invocar um direito contra outro particular e invocar esse direito perante uma jurisdição nacional.

Embora o Tribunal de Justiça negue a possibilidade de efeito direto horizontal, ele declara a responsabilidade patrimonial do Estado pelos danos causados ao particular, por violação ao direito da União. Contudo, existem exceções aos posicionamentos aqui descritos, sendo que, em alguns casos particulares, o Tribunal de Justiça admite o efeito direto horizontal.

\subsubsection{Efeito direto triangular}

O efeito direto de uma diretiva também foi reconhecido nos casos de relação triangular. Contudo, di-

$155 \int 3^{\circ}$ do art. 189 do Tratado da CEE - A directiva vincula o Estado-membro destinatário quanto ao resultado a alcançar, deixando, no entanto, às instâncias nacionais a competência quanto à forma e aos meios.

156 UNIÃO EUROPÉIA. Tribunal de Justiça. Acórdão TJUE de 14 de Julho de 1994, Faccini Dori v. Recreb, Proc. C-91/92, Col. 1994, p. I -3325. ferentemente dos acórdãos até então expostos, o efeito direto triangular implica o efeito direto horizontal de uma diretiva, ou seja, a sua aplicação entre particulares.

O efeito direto triangular consiste na possibilidade de um particular invocar atos da União Europeia (o que abarca as diretivas) perante os tribunais nacionais em face não apenas dos Estados, mas também contra outros particulares, toda vez que um Estado-membro efetuar uma regulamentação interna diferente dos moldes determinados por um ato comunitário ou sem observar as disposições procedimentais contida nesses atos, e causar prejuízos a algum particular. Nesse caso específico, os particulares prejudicados poderão valer-se diretamente da norma contida na diretiva para afastar a aplicabilidade da norma nacional, mesmo que isso acarrete efeitos para outros particulares.

Um exemplo da situação triangular ocorreu no caso Arcor $A G$ \& Co. $K G^{157}$. O Tribunal de Justiça declarou que os operadores privados de telecomunicação podem invocar a legislação comunitária perante o tribunal nacional alemão, a fim de impugnar uma decisão da autoridade reguladora nacional. No caso em tela, a autoridade reguladora autorizou um encargo adicional sobre o preço das telecomunicações com origem na rede telefônica da Deutsche Telekom, a ser suportado pelos operadores concorrentes.

O Tribunal de Justiça manifestou-se no mesmo sentido em outros casos como Unilever Itália v. Central Food ${ }^{158}$. Nele, o Tribunal de Justiça manteve o entendi-

157 UNIÃO EUROPÉIA. Tribunal de Justiça. Acórdão TJUE de 17 de Julho de 2008, Arcor AG \& Co. KG, Proc 152/07, Col. 2008, p. I-05959. Pedido de decisão prejudicial — Bundesverwaltungsgericht — Interpretação da Directiva 90/388/CEE da Comissão, de 28 de Junho de 1990, relativa à concorrência nos mercados de serviços de telecomunicações (JO L 192, p. 10), e da Directiva 97/33/CE do Parlamento Europeu e do Conselho de 30 de Junho de 1997 relativa à interligação no sector das telecomunicações com o objectivo de assegurar o serviço universal e a interoperabilidade através da aplicação dos princípios da oferta de rede aberta (ORA) (JO L 199, p. 32) - Regulamentação nacional que prevê, além das tarifas de interligação calculadas em função do custo deste serviço, uma contribuição financeira dos outros operadores para cobrir o «défice no acesso» em que o operador estabelecido incorre pela oferta da linha de assinantes - Obrigação dos Estados-Membros suprimirem os obstáculos ao reajuste das tarifas pelos organismos históricos de telecomunicação na sequência da interligação de redes — Possibilidade de um particular invocar o efeito directo de uma directiva num tribunal de um Estado-Membro para obter a anulação de uma decisão administrativa que prevê uma obrigação financeira a favor de outro particular.

158 O caso refere-se a a lei interna, promulgada e que entrou em vigor no Estado-membro (Lei no 313 de 03 de agosto de 1998), 
mento esposado no caso Cia. Security Inernational, declarando que o objetivo da Diretiva 83/189 não é simplesmente informar a Comissão, mas sim eliminar ou restringir os entraves às trocas comerciais, informar os outros Estados das regulamentações técnicas projetadas por um Estado, "dar à Comissão e aos outros Estados-membros o tempo necessário para reagir e propor alterações que permitam atenuar as restrições à livre circulação de mercadorias decorrentes da medida prevista e deixar à Comissão o tempo necessário para propor uma diretiva de harmonização" ${ }^{\text {"159. }}$.

Por essa razão, o Tribunal de Justiça entendeu que embora uma diretiva não deva produzir efeito direto entre os particulares, essa regra não se aplica numa situação em que o Estado-membro desrespeitou o disposto na Diretiva 83/189, esse fato constitui um vício processual essencial, razão pela qual implica a inaplicabilidade da norma técnica adotada com inobservância da Diretiva.

\subsubsection{Efeito direto da diretiva que concretiza direitos fun- damentais e principios gerais do direito}

No caso Marleasing, ${ }^{160}$ o Tribunal de Justiça confirma a tese clássica esposada no acórdão Marshall e apenas reconhece à diretiva efeito direto vertical. Porém, Fausto de Quadros chama a atenção para o fato de que algumas vozes na doutrina têm interpretado este Acórdão "como parecendo ele admitir, ainda que de forma tími$\mathrm{da}$, e sempre por via indireta, o efeito direto horizontal de disposições de diretiva nas condições específicas deste caso concreto"161. Em suma, embora o Acórdão defende que a diretiva só possa ser invocada pelo Es-

pode não ser aplicada pelo juiz nacional chamado a proferir uma injunção para pagamento relativamente ao fornecimento de azeite extra-virgem rotulado de modo não conforme com as disposições nacionais da referida Lei, considerando que, após a notificação e consequênte análise de um projeto de lei nacional relativo a rotulagem de origem do azeite extra virgem, do azeite virgem e do azeite, a Comissão Europeia procedeu ao envio formal de um convite ao Estado em causa para não adotar, num prazo determinado, até 14 de setembro de 1999, normas relativas a comercialização do azeite. A não aplicabilidade da norma nacional decorreria da violação a obrigação de notificação prevista no art. $8^{\circ}$ da Diretiva 83/189.

159 UNIÃO EUROPÉIA. Tribunal de Justiça. Acórdão TJUE de 26 de Setembro de 2000, Unilever Itália, Proc. C-443/98, Col. 2000, p. I-07535.

160 UNIÃo EUROPÉIA. Tribunal de Justiça. Acórdão TJUE de 13 de Novembro de 1990, Marleasing, Proc. C-106/89, Col.1990, p. I-4.135.

161 QUADROS, Fausto de. Direito da União Europeia. Coimbra: Almedina, 2004. p. 437. tado, ele exige que os tribunais nacionais interpretem o direito nacional em conformidade com o texto e a finalidade da diretiva, esse fenômeno foi nomeado de efeito horizontal indireto. Além disso, no caso Smith and Nephew ${ }^{162}$, o tribunal de Justiça admitiu a invocação das disposições de uma diretiva contra uma decisão administrativa, quando sabia que essa invocação produziria efeitos diretos horizontais para um único particular, no caso uma empresa que participava de um concurso público $^{163}$.

Porém, em dois casos paradigmáticos, envolvendo direitos sociais do trabalhador, o Tribunal de Justiça concedeu a uma diretiva efeito direto horizontal, sendo que em um deles o prazo de transposição da diretiva não tinha sequer transcorrido, contrariando, assim, toda a jurisprudência firmada até então sobre o tema.

Em verdade, essa compreensão complementa a jurisprudência atual, sim, cria exceção à regra, mas de nenhum modo revoga as posições anteriores já firmadas pelo Tribunal de Justiça. Tudo o que foi dito sobre o efeito direto das diretivas ainda se encontra em vigor, mas há situações em que a regra pode ser excepcionada. A propósito, importa seguir na análise jurisprudencial.

No caso Mangold ${ }^{164}$, o Tribunal de Justiça pronunciou-se sobre a relação entre o princípio geral da não-discriminação em razão da idade e a Diretiva 2000/78, cujo prazo de transposição ainda decorria, e uma norma nacional alemã que contrariava a mencionada Diretiva. O Tribunal acabou por reconhecer a violação da proibição da não-discriminação em razão da idade, justificando que "a circunstância de, à data da celebração do contrato, o prazo de transposição da Diretiva 2000/78 ainda não ter expirado, não pode por em causa esta conclusão".

Fato é que aplicação da diretiva não é imediata, deve ser certa e incondicional. Porém, a incondicionalidade, é interpretada com frequência, nos casos da diretiva, como sendo o transcurso do prazo de transposição. Isso passa a ser relativizado para os casos em que uma diretiva consagra direitos fundamentais ou princípios

162 UNIÃO EUROPÉIA. Tribunal de Justiça. Acórdão TJUE de 12 de Novembro de 1996, Smith and Nephem, Proc. C-201/94, Col. 1996, p. I-05819.

163 QUADROS, Fausto de. Direito da União Europeia. Coimbra: Almedina, 2004. p. 438.

164 UNIÃO EUROPÉIA. Tribunal de Justiça. Acórdão TJUE de 22 de Novembro de 2005, Mangold, Proc C-144/04, Col. 2005, p. I-9981. 
gerais do direito. Essa relativização não é a derrogação do requisito de incondicionalidade da diretiva para os casos específicos descritos, mas, sim, sua flexibilização em prol do princípio da proporcionalidade, quando a diretiva se referir às matérias ora discutidas.

Maria Luísa Duarte equaciona a diretiva, em período de transposição, que consagra direitos fundamentais ou princípios gerais do direito, com efeito de excluir a aplicação da legislação-nacional, da seguinte forma:

\section{1) O Estado-membro adotou o normativo interno que põe em causa a diretiva (jurisprudência Wallonie); \\ 2) o Estado-membro procedeu a transposição antecipada e o seu direito passa a ser escrutinado pela ótica da diretiva transposta; \\ 3) a diretiva em causa apenas regula as condições de exercício de um direito de aplicação imediata, situação que se deve distinguir da diretiva de concretização ${ }^{165}$.}

A caminhada do Tribunal de Justiça no sentido de dar a máxima efetividade aos direitos fundamentais, afastando a legislação nacional, foi reforçada no caso Seda $a^{166}$.

S. Kücükdeveci era empregada da empresa Swedex, desde 04 de junho de 1996, época em que tinha 18 anos. Porém, foi despedida em 19 de dezembro de 2006. Em face do aviso prévio, a relação laboral estendeu-se até 31 de janeiro de 2007. Contudo, o empregador calculou o prazo de aviso prévio como se a trabalhadora tivesse apenas uma antiguidade de 3 anos, apesar de estar ao seu serviço há 10 anos.

S. Kücükdeveci alegou que o $\int 622, n^{\circ} 2$, segundo parágrafo, do BGB, na parte em que prevê que o tempo de trabalho prestado por um trabalhador antes dos 25 anos de idade não é contabilizado para calcular a duração do aviso prévio, constitui uma medida discriminatória baseada na idade, contrária ao direito da União Europeia, pelo que não deve ser aplicado, em virtude do prazo de transposição da Diretiva 2000/78 já ter terminado no dia em que ocorreu o despedimento.

É fundamental compreendermos se a questão deve ser analisada à luz do direito primário ou da Diretiva 2000/78. Sobre o tema, o Tribunal de Justiça foi categó-

165 DUARTE, Maria Luísa. O tempo e a transposição de diretivas no direito da União Europeia. In: ESTUDOS em homenagem a Miguel Galvão Teles. Coimbra: Almedina, 2012. v. 1. p. 423-439. 166 UNIÃo EUROPÉIA. Tribunal de Justiça. Acórdão TJUE, de 19 de Janeiro de 2010, SEDA, Proc. C-555/07, Col. 2010, p. I-365. rico e, reportando-se à jurisprudência iniciada no Acórdão Mangold, já referido, confirmou que a mencionada Diretiva não consagra, em si mesma, o princípio da igualdade de tratamento em matéria de emprego e trabalho, pelo contrário, esse princípio "encontra a sua origem em diversos instrumentos internacionais e nas tradições constitucionais comuns aos Estados-membros". O Tribunal de Justiça reconhece, assim, um princípio da não-discriminação em relação à idade, que deve ser considerado um princípio geral do direito da União. Porém, a Diretiva 2000/78, nas palavras do próprio Tribunal, não o instituiu, mas apenas concretizou esse princípio.

Além disso, o Tribunal de Justiça fundamentou a sua decisão no fato de que o art. $6^{\circ}, n^{\circ} 1$, TUE enuncia que a Carta dos Direitos Fundamentais da União Europeia tem o mesmo valor jurídico dos Tratados e nela está consignada, em seu art. $21^{\circ}, n^{\circ} 1$, a vedação da discriminação em razão da idade. Logo, não restam dúvidas de que a questão deve ser solucionada pela via do direito primário.

Por fim, para que o princípio da não-discriminação seja aplicável ao caso concreto, é necessário verificar se a situação debatida no litígio principal é abrangida pelo âmbito de aplicação do direito da União Europeia.

Nestas condições, o Tribunal de Justiça concluiu que o juiz nacional, chamado a se pronunciar em um litígio entre particulares, por força do princípio do primado do direito da União, de que o princípio da não-discriminação também beneficia, deve afastar uma legislação nacional que seja contrária ao direito da União, quando o instituto da interpretação conforme não puder ser utilizado. Como bem observa Maria Luísa Duarte ${ }^{167}$ :

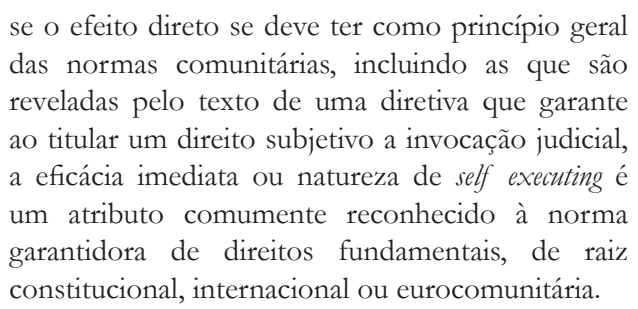

Assim, no bojo do caso Seda, foi novamente afastada norma nacional do direito alemão que feria os princípios gerais do direito, especificamente o direito fundamental da igualdade, e contrariava a Diretiva 2000/78. O Tribunal de Jutiça clareou ainda mais a natureza da

167 DUARTE, Maria Luísa. O tempo e a transposição de diretivas no direito da União Europeia. In: ESTUDOS em homenagem a Miguel Galvão Teles. Coimbra: Almedina, 2012. v. 1. p. 423-439. 
norma garantidora do direito da não-discriminação em razão da idade, ao explicar que a Diretiva 2000/78 "não consagra, em si mesma, o princípio da igualdade de tratamento em matéria de emprego e de trabalho, princípio esse que encontra a sua origem em diversos instrumentos internacionais e nas tradições constitucionais comuns aos Estados-membros."

Em suma, a Diretiva não consagra e, muito menos, introduz um princípio no ordenamento da União Europeia, ela simplesmente concretiza o exercício do direito. Maria Luísa Duarte esclarece o tema:

O direito da União fundamenta e impõe a proibição
da discriminação em razão da idade como
manifestação de um princípio geral do direito. A
Diretiva 2000/78, e outras de natureza análoga,
aprovadas com base no art. $19^{\circ}$, n ${ }^{\circ}$ 1, TFUE,
concretiza e modela o exercício do direito. O efeito
da substituição, traduzido na aplicação da norma
da Diretiva, depende do efetivo esgotamento
do prazo de transposição. Ao invés o efeito de
exclusão que pressupõe a desaplicação da norma
interna contrária constitui uma obrigação imediata
para o juiz nacional, ao qual compete aplicar o
direito da União, incluíndo, naturalmente, os
direitos fundamentais, que são expressão direta de
princípios gerais do direito ${ }^{168}$.

Os dois casos ora analisados são paradigmáticos porque concentram os dois objetivos que orientam o Tribunal de Justiça na sua prática de concretização dos direitos emados pelas diretivas: a tutela dos direitos fundamentais e uma maior eficácia jurídica às normas emanadas por diretivas. Não soa estranho falar que o Tribunal de Justiça identifica as diretivas como instrumento concretizador dos princípios gerais do direito, nesse caso visto como expressão garantidora de direitos fundamentais. Segundo Maria Luísa Duarte essa distinção entre título primário e secundário de reconhecimento de um determinado direito fundamental encontra eco no artigo 52, $\mathrm{n}^{\circ} 5^{\circ}$, da Carta dos Direitos Fundamentais da União Europeia (CDFUE) ${ }^{169}$. Porém, essa dicotomia entre direitos que são respeitados e princípios que devem ser observados vem sendo ignorada pelo Tribunal

168 DUARTE, Maria Luísa. O tempo e a transposição de diretivas no direito da União Europeia. In: ESTUDOS em homenagem a Miguel Galvão Teles. Coimbra: Almedina, 2012. v. 1. p. 423-439.

169 As disposições da presente Carta que contenham princípios podem ser aplicadas através de actos legislativos e executivos tomados pelas instituições, órgãos e organismos da União e por actos dos Estados-Membros quando estes apliquem o direito da União, no exercício das respectivas competências. Só serão invocadas perante o juiz tendo em vista a interpretação desses actos e a fiscalização da sua legalidade. de Justiça, que não difere os efeitos dos dois veículos normativos. Essa aproximação de efeitos ganha ainda mais força com o Tratado de Lisboa que concedeu a CDFUE o mesmo efeito dos Tratados ${ }^{170}$.

Desta forma, percebe-se que os dois casos acima expostos conduziram o Tribunal de Justiça a um novo patamar na construção sobre a eficácia jurídica da diretiva. Nessa fase, a ponderação se destaca como elemento essencial na interpretação de diretivas que concretizam direitos fundamentais ou que, de alguma forma, estejam relacionadas com a aplicação de princípios gerais do direito.

É importante frisar que o efeito direto e a aplicabilidade imediata de uma diretiva que concretiza direitos fundamentais ou princípios gerais do direito, no âmbito horizontal, ou seja, entre particulares, embora admitida pela jurisprudência do Tribunal de Justiça, não induz a ideia de que se tratra de uma regra, mas, sim, de instituto de aplicação subsidiária e "não dispensa a existência de uma ligação objetiva entre a diretiva e o princípio geral" ${ }^{\prime 171}$. Antes de aplicar a diretiva diretamente deve-se tentar obter a solução pela via interpretativa, nomeadamente, pela interpretação conforme da norma nacional em desacordo. Caso não seja possível, deve-se verificar, utilizando-se do princípio da proporcionalidade, se a responsabilidade extracontratual é suficiente para o caso concreto. Apenas depois de vencidas as fases anteriores e se a relação entre a diretiva e os princípios gerais ou direitos fundamentais for clara e objetiva, é que será possível afastar a norma interna em face da diretiva concretizadora.

\section{Considerações finais}

A diretiva é vista como instrumento de harmonização de legislações. Quando a matéria a ser legislada necessita ser uniforme, a União atua por meio dos regulamentos. Por essa razão, os regulamentos sempre têm efeito direto. Todavia, o efeito direto das diretivas é excepcional, pois, em regra, os particulares só poderão valer-se das normas contidas nas diretivas, após a sua transposição para o direito nacional.

170 DUARTE, Maria Luísa. O tempo e a transposição de diretivas no direito da União Europeia. In: ESTUDOS em homenagem a Miguel Galvão Teles. Coimbra: Almedina, 2012. v. 1. p. 423-439.

171 DUARTE, Maria Luísa. O tempo e a transposição de diretivas no direito da União Europeia. In: ESTUDOS em homenagem a Miguel Galvão Teles. Coimbra: Almedina, 2012. v. 1. 
Por isso, é bastante claro que as diretivas são normas dirigidas diretamente aos Estados-membros. Contudo, transmitem uma certa "ideia de Europa" que é almejada pela União Europeia, razão pela qual, indiretamente, elas são também dirigidas aos cidadãos da União. Porém, o principal efeito de uma diretiva é gerar uma obrigação de transposição para o Estado-membro destinatário.

Os regulamentos são atos supranacionais, exprimem uma relação de supremacia do direito da União sobre o direito interno. As diretivas, por sua vez, carecem dessa supremacia, sendo um ato eminentemente de cooperação entre a União e a ordem interna. Porém, apesar dessa ausência de subordinação, durante o período de transposição, os Estados devem abster-se de adotar quaisquer medidas que possam comprometer o resultado prescrito pelas diretivas, competindo aos tribunais nacionais controlar a legalidade das disposições nacionais.

Caso o Estado destinatário não transponha a diretiva no prazo estipulado, ou caso os seus órgãos não cumpram o disposto na diretiva, ou mesmo nos casos de errada e insuficiente transposição, o Estado incorre em situação de incumprimento, que pode resultar na abertura de um processo por não cumprimento.

É possível que o processo de não cumprimento seja substituído por uma ação de responsabilidade civil extracontratual a ser proposta contra o Estado faltoso nos seus tribunais nacionais, segundo as regras processuais próprias de cada Estado. Porém, uma vez que se trata de responsabilidade pela não implementação de uma diretiva, os critérios para a reparação do dano são os determinados pelo direito da União.

Depois de esgotado o prazo para a transposição de uma Diretiva e, ainda assim, caso o Estado destinatário tenha permanecido inerte, a diretiva goza de efeito direto vertical, caso ela seja precisa e incondicional. O efeito direto afigura-se como uma sanção para o Estado pelo fato de ele não ter cumprido a sua obrigação em tempo hábil ou o tenha feito de maneira incorreta, isso ocorre quando o Estado transpõe mal uma diretiva.

O direito de invocar o efeito direto constitui apenas uma garantia mínima para os particulares, decorrente do caráter vinculativo das obrigações impostas aos Estados-membros por força das diretivas.

Durante o período de transposição, o Estado-membro não pode agir de forma contrária à diretiva, emitin- do atos legislativos ou regulatórios que dificultem ou contrariem a diretiva que se encontra em período de transposição, ou seja, não é que os particulares tenham direito à aplicação direta e imediata de uma diretiva no período de transposição, mas, sim, que o Estado-membro não pode efetivar atos contrários à diretiva durante esse período. Assim, caso o Estado-membro não observe essa obrigação de não fazer, os particulares poderão exigir nos tribunais nacionais a não-aplicação da norma ou, em pedido alternativo, que o Estado seja condenado a indenizar por violação do princípio da confiança legítima.

O efeito direto das diretivas pode ser sintetizado da seguinte forma:

1) Diretivas imprecisas e/ou condicionais: não possuem efeito direto, ainda que o prazo de transposição já tenha transcorrido e o Estadomembro tenha permanecido inerte;

2) Diretivas precisas e incondicionais:

2.1. prazo de transposição não transcorrido: em regra, não possui efeito direto;

2.2. prazo de transposição transcorrido e Estado inerte: efeito direto vertical ascendente;

2.3. entre particulares: embora seja desprovida do efeito horizontal, o juiz nacional deve utilizar-se da interpretação conforme, o que parte da doutrina nomeia de efeito indireto horizontal, isso deve ser feito mesmo antes do prazo de transposição ter decorrido.

Contudo, há exceções às regras acima transcritas. A jurisprudência do Tribunal de Justiça, em alguns casos específicos, permite o efeito direto de uma diretiva entre particulares, ou seja, consagra o efeito horizontal, algumas vezes, mesmo antes de transcorrido o prazo de transposição.

Assim, em caso de não transposição de diretiva precisa e incondicional, os particulares podem invocá-la diretamente contra outros particulares, nos casos de efeito direto triangular, ou seja, toda vez que um Estado-membro efetuar uma regulamentação interna diferente dos moldes determinados por um ato comunitário ou sem observar as disposições procedimentais contida nesses atos e causar prejuízos a algum particular pelo fato dele 
não ter observado o disposto em determinada diretiva. Nesse caso específico, os particulares prejudicados poderão valer-se diretamente da norma contida na diretiva para afastar a aplicabilidade da norma nacional, mesmo que isso acarrete efeitos a outros particulares.

As diretivas também terão efeitos horizontais, mesmo antes de findo o prazo de transposição, quando uma diretiva concretizar princípios gerais do direito ou direitos fundamentais. Em matéria de direitos fundamentais, a União Europeia, após o Tratado de Lisboa, passa a estar vinculada, formalmente, à Carta de Direitos Fundamentais, que está equiparada à mesma força jurídica dos Tratados. Logo, dúvida não há: os direitos fundamentais, atualmente, são fontes originárias do direito da União Europeia. Claro, a não-observância do termo final do prazo de transposição, a fim de aplicar horizontalmente uma diretiva, deverá ser norteada pelo princípio da proporcionalidade. Na verdade, nesse último caso, não é exatamente a diretiva que tem efeito direto, mas, sim, a norma que está contida na diretiva que produz efeito direto, uma vez que a diretiva não introduz direitos fundamentais ou princípios gerais do direito no ordenamento da União Europeia. Já são fontes primárias desse ordenamento. Assim, nesses casos, os direitos fundamentais e os princípios gerais do direito é que têm efeito direto, independentemente do tipo de norma que os explicitem.

Contudo, o efeito direto e a aplicabilidade imediata de uma diretiva que concretiza direitos fundamentais ou princípios gerais do direito no âmbito horizontal, ou seja, entre particulares, embora admitida pela jurisprudência do Tribunal de Justiça, não induz a ideia de que se tratra de uma regra, mas, sim, instituto de aplicação subsidiária, sem falar que é fundamental que exista uma ligação objetiva entre a diretiva e o princípio geral ou direito fundamental. Além disso, antes de aplicar a diretiva diretamente, deve-se tentar obter a solução pela via interpretativa, nomeadamente pela interpretação conforme da norma nacional em desacordo. Caso não seja possível, deve-se verificar, utilizando-se do princípio da proporcionalidade, se a responsabilidade extracontratual é suficiente para o caso concreto. Apenas depois de vencidas as fases anteriores é que será possível afastar a norma interna em face da diretiva concretizadora, desde que observando o critério de "adequação funcional".

\section{RefERÊNCIAS BIBLIOGRÁFICAS}

ALMEIDA, Elizabeth Accioly Pinto de. Mercosule União Européia: estrutura jurídico-institucional. Curitiba: Juruá, 2004.

BARRIONUEVO, María Bellido. La directiva comunitaria. Madrid: Dykinson, 2003.

BORCHARDT, Klaus-Dieter. $O A B C$ do direito comunitário. 1986. Disponível em <http://www.dhnet.org.br/direitos/sip/euro/ue_abc_dir_comunitario.pdf $>$. Acesso em: 05 jun. 2013.

CAMPOS, João da Mota. Manual de direito comunitário. 3. ed. Lisboa: Fundação Caloute Gulbenkian, 2002

CAMPOS, João Luiz Mota. Manual de direito europeu: o sistema institucional, a ordem jurídica e ordenamento económico da União Europeia. 6. ed. Coimbra: Coimbra, 2010.

COELHO, Teresa Leal. A jurisprudência do Tribunal de Justiça das comunidades relativa ao efeito directo da directiva comunitária. Disponível em: <http://www.estig.ipbeja. pt/ ac_direito/caracterizacao_oj__comunitaria.pdf $>$. Acesso em: 04 maio 2013.

CRUZ VILAÇA, José Luís. A propósito dos efeitos das directivas na ordem jurídica dos Estados-membros. Justiça Administrativa, n. 30, p. 3-19, nov./dez. 2001.

CUNHA, Luís Pedro. Considerações sobre a possibilidade de adesão da comunidade à Convenção Europeia dos Direitos do Homem. Gestão e Desenvolvimento, v. 2, p. 35-52, 1993. Disponível em: <http://www.estig.ipeja. $\mathrm{pt} / \sim$ ac_direito/gestaododesenvolvimento2_35.pdf $>$. Acesso em: 24 ago. 2013.

CUNHA, Ricardo Sousa da. Introdução diacrónica e incrónica ao direito da União Europeia. Disponível em: <https:// woc.ipca.pt $/$ esg $/$ getFile.do?tipo $=2 \& i d=7633 \square>$. Acesso em: 03 ago. 2013.

DROMI, José Roberto; EKMEKDJIAN, Miguel Angel; RIVERA, Julio César. Derecho comunitario: sistemas de integración, régimen del Mercosur. Ciudad Argentina 1995.

DUARTE, Maria Luísa. Estudos de direito da União e das Comunidades Europeias, II. Coimbra: Coimbra, 2006.

DUARTE, Maria Luísa. O Tempo e a transposição de diretivas no direito da União Europeia. In: ESTUDOS em homenagem a Miguel Galvão Teles. Coimbra: Al- 
medina, 2012. v. 1. p. 423-439.

DUARTE, Maria Luísa. União Europeia e direitos fundamentais. Lisboa, 2006.

DUARTE, Maria Luísa. União Europeia: estática e dinâmica da ordem jurídica Eurocomunitária. Coimbra: Almedina, 2011.

FERREIRA, Lier Pires; FRAGOSO, Geraldo. O direito comunitário na União Europeia. VoxJuris, ano 1, v. 1, n. 1, p. 115-131, 2008. Disponível em: <https://ugf.br/ files/stricto/direito/revista/14.artigo.07.pdf> Acesso em: 05 ago. 2013.

FORTE, Umberto. União Europeia: Comunidade Econômica Europeia: Direito das Comunidades Europeias e harmonização fiscal. São Paulo: Malheiros, 1994.

GOMES, José Caramelo. Lições de direito da União Europeia. Coimbra: Almedina. 2011.

KENT, Penelope. Law of the European Union. 2. ed. London: M\&E Pitman Publishion, 1996.

LEAL, Rosemiro Pereira. Curso de direito econômico comunitário. Porto Alegre: Síntese, 2002.

MANIN, Ph. L'invocabilité des directives: quelques interrogations. Revue Trimestrielle de Droit Européen, 1990.

MARTINS, Ana Maria Guerra. Constitucionalismo Europeu e direitos fundamentais após o Tratado de Lisboa. Instituto de Ciência Jurídico-Politicas. Disponível em: < http:// www.icjp.pt/sites/default/files/media/822-1351.pdf>. Acesso em: 14 ago. 2013.

MARTINS, Ana Maria Guerra. Curso de direito constitucional da União Europeia. Coimbra: Almedina, 2004.

MÉGRET, Jacques. Le droit de la Communauté économique européenne: pt. 1-2. La cour de justice, les actes des institutions. Bruxelles: Universitaires de Bruxelles, 1983.

MOREIRA, Vital. O tempo e a transposição de diretivas no direito da união europeia. In: ESTUDOS em homenagem a Miguel Galvão Teles. Coimbra: Almedina, 2012. v. 1. p. 717-745.

NASCIMENTO, Cláudia Lyra. O dilema da incorporação das normas do Mercosul no ordenamento jurídico brasileiro. Revista de Informação Legislativa, Brasília, ano 43, n. 172, out./dez. 2006. Disponível em: < http:/ / www2.senado.gov.br/bdsf/item/id/93272>. Acesso em: 10 abr. 2013.

PEREIRA, André Gonçalves; QUADROS, Fausto de.
Direito internacional público. 3. ed. Coimbra, 1993.

PESCATORE, Pierre. The doctrine of 'direct effect': an infant disease of community law. Euro-pean Law Review, n. 8, 1983.

PIZZOLO, Calogero. Globalizacion e integration: integración: ensayo de una teoría general: Comunidad Andina, Mercosur, Unión Europea, SICA. Buenos Aires: Ediar, 2002.

PRECHAL, Sacha. Directives in European Community law. Oxford: Clarendon, 1995.

QUADROS, Fausto de. Direito da União Europeia. Coimbra: Almedina, 2004.

RAMOS, Rui Manoel Moura. Das comunidades à União Europeia. Coimbra: Coimbra, 1994.

SOUSA, Marcelo Rebelo de. A transposição das directivas comunitárias para a ordem jurídica nacional. INA, Oeiras, v. 4-5, p. 69-94, abr./dez. 1992.

TIMMERMANS, Christiaan. Community directives revisited. Yearbook of European Law, v. 17, n. 1, p. 1-28, 1997.

UNIÃO EUROPÉIA. Tribunal de Justiça. Acórdão TJUE de 03 de Dezembro de 1974, Van binsbergen, Proc. C- 33/74. Col. 1974, p. 543.

UNIÃO EUROPÉIA. Tribunal de Justiça. Acórdão TJUE de 04 de Dezembro de 1974, Van Duyn, Proc. 41/74, Col. 1974, p. 567.

UNIÃO EUROPÉIA. Tribunal de Justiça. Acórdão TJUE de 04 de Fevereiro de 1959, Stork, Proc 01/58, Col. 1959, p. 293.

UNIÃO EUROPÉIA. Tribunal de Justiça. Acórdão TJUE de 06 de Outubro de 1970, Franz Grad, Proc. 9/70, Rec. 1970, p. 825.

UNIÃO EUROPÉIA. Tribunal de Justiça. Acórdão TJUE de 08 de Abril de 1976, Defrenne v. Sabena, Proc. 43/75, Col. 1976, p. 193.

UNIÃO EUROPÉIA. Tribunal de Justiça. Acórdão TJUE de 08 de Outubro de 1987, Nijmegen, Proc. 80/86, Col. 1987, p. 3969.

UNIÃO EUROPÉIA. Tribunal de Justiça. Acórdão TJUE de 09 de Marro de 1978, Simmenthal, Proc. 106/77, Col. 1978, p. 629.

UNIÃO EUROPÉIA. Tribunal de Justiça. Acórdão TJUE de 10 de Novembro de 1992, Hansa Fleisch, Proc. 
C-156/91, Col. 1992, p. I-05567.

UNIÃO EUROPÉIA. Tribunal de Justiça. Acórdão TJUE de 10 de Outubro 1973, Variola, 34/73, Col. 1973, p. 365.

UNIÃO EUROPÉIA. Tribunal de Justiça. Acórdão TJUE de 11 de Julho de 1985, Cinètheque, Procs. $60 \mathrm{e}$ 61/84, Col. 1985, p. 2605.

UNIÃO EUROPÉIA. Tribunal de Justiça. Acórdão TJUE de 12 de Dezembro de 1970, Internacionalde Handelsgesellschaft, Proc 11/70, Rec. 1970, p. 1125.

UNIÃO EUROPÉIA. Tribunal de Justiça. Acórdão TJUE de 12 de Novembro de 1960, Stauder, Proc 26/69, Rec 1969, p. 419.

UNIÃO EUROPÉIA. Tribunal de Justiça. Acórdão TJUE de 12 de Novembro de 1996, Smith and Nephew, Proc. C-201/94, COL. 1996, p. I-05819.

UNIÃO EUROPÉIA. Tribunal de Justiça. Acórdão TJUE de 13 de Dezembro de 1988, proferido no Proc. 322/88, Salvatore Grimaldi v. Fonds, Col. 1989, p. 4407.

UNIÃO EUROPÉIA. Tribunal de Justiça. Acórdão TJUE de 13 de Maio de 1962, Consórcio de Carvão do Ruhr, Proc 13/60, Col. 1962, p. 307.

UNIÃO EUROPÉIA. Tribunal de Justiça. Acórdão TJUE de 13 de Novembro de 1990, Marleasing, Proc. C-106/89, Col.1990, p. I-4.135.

UNIÃO EUROPÉIA. Tribunal de Justiça. Acórdão TJUE de 14 de Dezembro de 1971, Politi, Proc. 43/71, Col. 1971, p. 419.

UNIÃO EUROPÉIA. Tribunal de Justiça. Acórdão TJUE de 14 de Julho de 1994, Faccini Dori v. Recreb, Proc. C-91/92, Col. 1994, p. I - 3325.

UNIÃO EUROPÉIA. Tribunal de Justiça. Acórdão TJUE de 14 de Maio de 1974, Nold II, Processo 4/73, Rec. 1974, p. 491.

UNIÃO EUROPÉIA. Tribunal de Justiça. Acórdão TJUE de 14 de Setembro de 2000, Trevor and Penny Fisher, C-369/98, Col. 2000, p. I-6751.

UNIÃO EUROPÉIA. Tribunal de Justiça. Acórdão TJUE de 15 de Julho de 1964, Costa c. Enel, Proc. 06/64, Col. 1964, p. 549.

UNIÃO EUROPÉIA. Tribunal de Justiça. Acórdão TJUE de 17 de Dezembro de 1970, Sace, Proc. 33/70, Col. 1969/1970, p. 685.
UNIÃO EUROPÉIA. Tribunal de Justiça. Acórdão TJUE de 17 de Julho de 2008, Arcor AG \& Co. KG, Proc 152/07, Col. 2008, p. I-05959.

UNIÃO EUROPÉIA. Tribunal de Justiça. Acórdão TJUE de 17 de Novembro de 1992, Comissão c. Irlanda, Proc. C-235/91, Col., p. I-5.917.

UNIÃO EUROPÉIA. Tribunal de Justiça. Acórdão TJUE de 18 de Dezembro de 1997, Inter-Environnement, Proc. C-129/96, Col., p. I-411.

UNIÃO EUROPÉIA. Tribunal de Justiça. Acórdão TJUE de 19 de maio de 1999, Comissão/França, C-225/97, Rec. I-3011, n 37

UNIÃO EUROPÉIA. Tribunal de Justiça. Acórdão TJUE de 21 de Junho de 1974, Reyners, Proc. C-2/74, Col. 1974, p. 325.

UNIÃO EUROPÉIA. Tribunal de Justiça. Acórdão TJUE de 21 de Março de 1997, Comissão/Bélgica, 102/79, Rec. $1473, \mathrm{n}^{\circ} 12$.

UNIÃO EUROPÉIA. Tribunal de Justiça. Acórdão TJUE de 22 de fevereiro de 1984, Kloppenburg, Proc. 70/83, Col., p. 1075.

UNIÃO EUROPÉIA. Tribunal de Justiça. Acórdão TJUE de 22 de Novembro de 2005, Mangold, Proc C-144/04, Col. 2005, p. I-9981.

UNIÃO EUROPÉIA. Tribunal de Justiça. Acórdão TJUE de 23 Abril de 1995, Comissão/Grécia, Proc. C-365/93, Col. 1995, p. I-499

UNIÃO EUROPÉIA. Tribunal de Justiça. Acórdão TJUE de 25 de Maio de 1982, Comissão c. Países Baixos, Proc. 96/81, Col., p. 1791.

UNIÃO EUROPÉIA. Tribunal de Justiça. Acórdão TJUE de 25 de Outubro de 1975, Rutili, Processo 36/75, Col. 1975, p. 415.

UNIÃO EUROPÉIA. Tribunal de Justiça. Acórdão TJUE de 26 de Setembro de 2000, Unilever Itália, Proc. C-443/98, Col. 2000, p. I-07535.

UNIÃO EUROPÉIA. Tribunal de Justiça. Acórdão TJUE de 27 de abril de 1989, Comissão c. Itália, Proc. 324/87, Col., p. 1013 e ss.

UNIÃO EUROPÉIA. Tribunal de Justiça. Acórdão TJUE de 3 de Abril de 1994, Vaneetveld, Proc. C-316/93, Col., pgs. I-763 e segs.

UNIÃO EUROPÉIA. Tribunal de Justiça. Acórdão 
TJUE de 5 de Fevereiro de 1963, Van Gend en Loos, Proc 26/62, Col. 1963, p. 00205.

UNIÃO EUROPÉIA. Tribunal de Justiça. Acórdão TJUE de 5 de Fevereiro de 1963, Van Gend en Loos, Proc 26/62, Col. 1963, p. 00205 e seg.

UNIÃO EUROPÉIA. Tribunal de Justiça. Acórdão TJUE de 6 de outubro de 1970, Franz Grad, Proc. 09/70, Rec., p. 825.

UNIÃO EUROPÉIA. Tribunal de Justiça. Acórdão TJUE, de 19 de Janeiro de 2010, SEDA, Proc. C-555/07,
Col. 2010, p. I-365.

VAN GERVEN, Walter. The horizontal effect of directive provisions revisited: the reality of Catchwords. University of Hull, Institute of European Public Law, 1993.

WINTER, Jan A. Direct applicability and direct effect: Two distinct and different concepts in Community law. Common Market Law Review, v. 9, n. s 425, 1972.

ZULEEG, Manfred. Fundamental rights and the law of the European Communities. Common Mkt. L. Rev. v. 8, 1971. 
Para publicar na Revista de Direito Internacional, acesse o endereço eletrônico www.rdi.uniceub.br ou www.brazilianjournal.org.

Observe as normas de publicação, para facilitar e agilizar o trabalho de edição. 